\title{
How and Why Are Cancers Acidic? Carbonic Anhydrase IX and the Homeostatic Control of Tumour Extracellular $\mathrm{pH}$
}

\author{
Shen-Han Lee ${ }^{1, *(\mathbb{B})}$ and John R. Griffiths ${ }^{2}$ (i) \\ 1 Department of Otorhinolaryngology, Hospital Sultanah Bahiyah, Jalan Langgar, \\ Alor Setar 05460, Kedah, Malaysia \\ 2 Cancer Research UK Cambridge Institute, University of Cambridge, Li Ka Shing Centre, Robinson Way, \\ Cambridge CB2 0RE, UK; john.griffiths@cruk.cam.ac.uk \\ * Correspondence: shen-han.lee@cantab.net
}

Received: 17 May 2020; Accepted: 15 June 2020; Published: 18 June 2020

\begin{abstract}
The acidic tumour microenvironment is now recognized as a tumour phenotype that drives cancer somatic evolution and disease progression, causing cancer cells to become more invasive and to metastasise. This property of solid tumours reflects a complex interplay between cellular carbon metabolism and acid removal that is mediated by cell membrane carbonic anhydrases and various transport proteins, interstitial fluid buffering, and abnormal tumour-associated vessels. In the past two decades, a convergence of advances in the experimental and mathematical modelling of human cancers, as well as non-invasive $\mathrm{pH}$-imaging techniques, has yielded new insights into the physiological mechanisms that govern tumour extracellular $\mathrm{pH}\left(\mathrm{pH}_{\mathrm{e}}\right)$. In this review, we examine the mechanisms by which solid tumours maintain a low $\mathrm{pH}_{\mathrm{e}}$, with a focus on carbonic anhydrase IX (CAIX), a cancer-associated cell surface enzyme. We also review the accumulating evidence that suggest a role for CAIX as a biological $\mathrm{pH}$-stat by which solid tumours stabilize their $\mathrm{pH}_{\mathrm{e}}$. Finally, we highlight the prospects for the clinical translation of CAIX-targeted therapies in oncology.
\end{abstract}

Keywords: cancer microenvironment; tumour $\mathrm{pH}$; carbonic anhydrase IX; cancer metabolism; $\mathrm{pH}$-stat; $\mathrm{pH}$ measurement in vivo; magnetic resonance spectroscopy; models of tumour $\mathrm{pH}$ regulation

\section{Introduction}

The $\mathrm{pH}$ of extracellular fluid $\left(\mathrm{pH}_{\mathrm{e}}\right)$ in healthy tissues is tightly regulated between 7.35 and 7.45 , in order to sustain normal physiology and cellular metabolism. In contrast, the $\mathrm{pH}_{\mathrm{e}}$ of cancers is acidic, between 6.3 and 7.0, reflecting the dysregulation of the acid-base homeostatic mechanisms that operate within solid tumours.

Almost a century ago, Otto Warburg published his seminal observation, termed aerobic glycolysis, in which tumour slices metabolized glucose into lactic acid instead of $\mathrm{CO}_{2}$, even in the presence of oxygen [1]. This observation, now termed 'The Warburg Effect' gave rise to the erroneous assumption that lactic acid produced by cancer cells would tend to acidify their cytoplasm and thus lower their intracellular $\left(\mathrm{pH}_{\mathrm{i}}\right)[2,3]$. Microelectrode studies on solid tumours appeared to support the assertion that tumours were acidic, and for half a century it was believed that both their $\mathrm{pH}_{\mathrm{i}}$ and their $\mathrm{pH}_{\mathrm{e}}$ were acidic. That dogma was overturned by the first magnetic resonance spectroscopy (MRS) studies on cancer in the early 1980s [4-6], which demonstrated that the $\mathrm{pH}_{\mathrm{i}}$ of solid tumours, both in animal models and in patients, was usually on the alkaline side of neutrality, much like that of normal cells. Subsequent MRS studies using extracellular $\mathrm{pH}$ probes, such as 3-aminopropylphosphonate (3-APP) [7] and the imidazole probes 2-imidazole-1-yl-3-ethoxycarbonyl propionic acid (IEPA) [8] and ( \pm )2-(imidazol-1-yl) 
succinic acid (ISUCA) [9], firmly established the conclusion that it was the extracellular, interstitial space of tumours that was acidic, with typical $\mathrm{pH}_{\mathrm{e}}$ values of 6.3-7.0.

In the last two decades, the acidic tumour microenvironment has become recognized as a feature of the tumour phenotype that drives the progression of cancer. It modulates several steps along the spectrum from preneoplasia to neoplasia, and then along the invasion-metastasis cascade, thus conferring an evolutionary advantage on solid tumours. Several reviews have discussed aspects of this process [10-12]. In parallel, advances in imaging technology, biophysics and chemistry have converged with the progress in experimental modelling of human cancers to yield novel insights into the mechanisms that cause and regulate the acidic tumour $\mathrm{pH}_{e}$; the enzyme carbonic anhydrase IX (CAIX) has been found to play a key role in these mechanisms. From a clinical perspective, the acidic tumour $\mathrm{pH}_{\mathrm{e}}$ is also an emerging diagnostic and therapeutic target. While current targeted therapies in oncology mostly focus on precise molecular targets such as receptor tyrosine kinases [13,14], microRNAs [15,16], or the ubiquitin-proteasome pathway $[17,18]$, the acidic tumour $\mathrm{pH}_{\mathrm{e}}$ is an attractive target because it is a common phenotype that is found across a wide spectrum of cancers. In this review, we will discuss the common imaging techniques and their applications in various experimental models of cancer. We will also highlight the experimental findings that inform how CAIX regulates tumour $\mathrm{pH}_{\mathrm{e}}$, and discuss the implications of these findings concerning the pathophysiology of disease progression.

\section{Methods for Measuring Tumour $\mathrm{pH}$}

Techniques for measuring $\mathrm{pH}$ in living systems are central to the study of tumour $\mathrm{pH}_{\mathrm{e}}$. They have been extensively reviewed elsewhere [19,20]; however, we will briefly introduce some of the major techniques to facilitate our subsequent discussion concerning their applications in cancer models.

The first measurements of tissue $\mathrm{pH}$ in vivo used microelectrodes, which measure the potential differences of solutions with differing proton concentrations across a thin glass membrane. The electrodes used in living tissues are much larger than cells, so they mainly measure $\mathrm{pH}_{\mathrm{e}}$. The principle disadvantage of microelectrode $\mathrm{pH}$ measurement is that it is invasive and causes damage to cells.

Today, many non-invasive imaging modalities have been developed to measure tissue $\mathrm{pH}$, including magnetic resonance, fluorescence imaging, positron emission tomography (PET) and single-photon emission computerized tomography (SPECT). They rely on a variety of mechanisms to generate image contrast, and have a wide range of spatial resolution. While these techniques have been useful in the preclinical setting, none of them have entered routine medical use, although efforts are underway to translate some of them into the clinic. Table 1 summarizes the range of non-invasive or minimally invasive techniques available for measuring tissue $\mathrm{pH}_{\mathrm{e}}$. 
Table 1. Summary of the non-invasive techniques for measuring tissue $\mathrm{pH}$.

\begin{tabular}{ll}
\hline Imaging Technique & \multicolumn{1}{c}{ Description } \\
\hline & Various fluorescent dyes and proteins exhibit a \\
& wavelength shift upon protonation. Ratiometric \\
& measurement of the fluorescent output at each \\
& wavelength allows the calculation of $\mathrm{pH}$. \\
& Advantage: very high spatial resolution $(<1 \mu \mathrm{m})$ \\
& enables the measurement of subcellular pH gradients \\
& Disadvantage: low penetration of the tissue limits its \\
& use in whole animal and clinical imaging. \\
& The use of SNARF-1 fluorescent dye on tumours grown \\
& in dorsal window chamber models has enabled the \\
& in vivo imaging of tumour pH [21,22]. \\
\hline
\end{tabular}
in vivo imaging of tumour $\mathrm{pH}[21,22]$

MRS measures the $\mathrm{pH}$-dependent chemical shift of MRS-visible nuclei such as ${ }^{1} \mathrm{H},{ }^{31} \mathrm{P}$, and ${ }^{19} \mathrm{~F}$ in endogenous or exogenous compounds. In compounds with $\mathrm{pK}_{\mathrm{a}}$ close to the physiological range, this property can be exploited to measure $\mathrm{pH}$ by comparing the chemical shift of the $\mathrm{pH}$-sensitive peak with a previously constructed titration curve of chemical shift vs. $\mathrm{pH}$.

${ }^{31} \mathrm{P}$ MRS can be used to measure $\mathrm{pH}_{\mathrm{i}}$ from the chemical shift of endogenous inorganic phosphate, while $\mathrm{pH}_{\mathrm{e}}$ can be measured with the use of

3-aminopropylphosphonate (3-APP). However, because of the low sensitivity of the ${ }^{31} \mathrm{P}$ nucleus, this technique has poor spatial resolution, and cannot be used to generate $\mathrm{pH}_{\mathrm{e}}$ maps $[7,23,24]$.

${ }^{19} \mathrm{~F}$ MRS can be used to measure $\mathrm{pH}_{\mathrm{e}}$ with ZK-150471

(3-[N-(4-fluoro-2-trifluoromethylphenyl)-sulfamoyl]propionic acid) and fluorinated vitamin B6 derivatives (6-fluoropyriodoxol \& 6-fluoropyridoxamine) [25]. ${ }^{1} \mathrm{H}$ magnetic resonance spectroscopic imaging (MRSI) of the imidazole-containing compounds, $( \pm)$ 2-(imidazol-1-yl)3-ethoxycarbonylpropionic acid (IEPA) [8] and ( \pm )2-(imidazol-1-yl) succinic acid (ISUCA) [9] can be used to generate $\mathrm{pH}_{\mathrm{e}}$ maps with a spatial resolution of 1-2 $\mathrm{mm}$. However, the poor temporal resolution of 10-30 min precludes measurement of $\mathrm{pH}$ changes.

Dissolution dynamic nuclear polarization (d-DNP) results in a substantial increase in the magnetic resonance (MR) signal [26], allowing measurements of spatial and temporal changes in $\mathrm{pH}_{\mathrm{e}}$ from exogenously administered hyperpolarized molecules.

Tumour $\mathrm{pH}_{\mathrm{e}}$ can be measured with hyperpolarized $\mathrm{H}^{13} \mathrm{CO}_{3}{ }^{-}$using the ratio of the peak intensities of $\mathrm{H}^{13} \mathrm{CO}_{3}{ }^{-}$and ${ }^{13} \mathrm{CO}_{2}$ [27].

However, this technique is dependent on carbonic anhydrase activity, and in tissues with low carbonic anhydrase activity, the measured $\mathrm{pH}$ will tend to be overestimated [28].

Hyperpolarised (HP) ${ }^{13} \mathrm{C}$ MR imaging $\mathrm{pH}_{\mathrm{i}}$ can be quantified from $\mathrm{HP}{ }^{13} \mathrm{CO}_{2}$ produced from $\left[1-{ }^{13} \mathrm{C}\right]$ pyruvate in organs with a high pyruvate dehydrogenase flux, e.g., the heart [29]. The short $\mathrm{T}_{1}$ of $\left[{ }^{13} \mathrm{C}\right]$ bicarbonate limits spatial resolution [27]. The current resolution of $2-10 \mathrm{~mm}$ is coarser than that of some other MR imaging approaches.

Other ${ }^{13} \mathrm{C}$-labelled compounds have been shown to be able to measure in vivo $\mathrm{pH}_{\mathrm{e}}$ using $\mathrm{HP}{ }^{13} \mathrm{C}$ MRS:

$\mathrm{N}$-(2-acetamido)-2-aminoethanesulfonic acid (ACES)

[30], diethylmalonic acid (DEMA) [31], zymonic acid [32], and amino acid derivatives [33]. 
Table 1. Cont.

\begin{tabular}{cl}
\hline \multicolumn{1}{c}{ Imaging Technique } & \multicolumn{1}{c}{ Description } \\
\hline & CEST measures $\mathrm{pH}_{\mathrm{e}}$ from the relative rates of \\
protonation and deprotonation of amide functional & groups on either endogenous molecules or \\
administered contrast agents. It has the advantage of & high spatial resolution $(0.1-2 \mathrm{~mm}$ ) but has \\
& low sensitivity. \\
Chemical exchange saturation transfer (CEST) & AcidoCEST is a CEST-based method of measuring $\mathrm{pH}_{\mathrm{e}}$ \\
& based on exogenous contrast agent administration [34]. \\
& Iopidamol, a United States Drug and Food Agency \\
& (FDA)-approved contrast agent, has been used with \\
& this approach to measure pH $\mathrm{H}_{\mathrm{e}}$ in metastatic ovarian \\
& cancer tumour models [35].
\end{tabular}

$\mathrm{pH}$ is measured from paramagnetic contrast agents with a $\mathrm{pH}$-dependent change in $\mathrm{T}_{1}$ relaxation time. It has the advantage of high signal-to-noise ratio and spatial resolution $(0.2-2 \mathrm{~mm})$. However, to accurately measure the $\mathrm{pH}$, this technique requires the

MR relaxometry administration of a second $\mathrm{pH}$-insensitive agent to correct the concentration of the $\mathrm{pH}$-sensitive agent. An example of the agent is GdDOTA-4AmP ${ }^{5-}$, a $\mathrm{pH}$-dependent chelate which has been used together with a pH-independent analogue, GdDOTP ${ }^{5-}$, to generate high spatial resolution maps of tissue $\mathrm{pH}_{\mathrm{e}}$ in a rat glioma model [36].

In vivo $\mathrm{pH}_{\mathrm{e}}$ imaging using positron emission tomography (PET) has been achieved using ${ }^{11}$ C-dimethyloxazolidinedione (DMO) [37], ${ }^{11} \mathrm{CO}_{2}$ [38], and ${ }^{123}$ I-labeled derivatives of malonic acid [39]. $\mathrm{pH}$ (low) insertion peptides (pHLIP) is a class of acid-targeting peptides that are activated to insert across the membrane of cancer cells by the acidity at the cell surface. These peptides can be conjugated with ${ }^{64} \mathrm{Cu}$ to target the radioisotope to regions where the $\mathrm{pH}_{\mathrm{e}}$ is below 7.0 [40].

PET/SPECT imaging

Caged derivatives of ${ }^{18} \mathrm{~F}$-fluorodeoxyglucose (FDG) can be localized to tumours by the release of the caging group in low $\mathrm{pH}_{\mathrm{e}}$, followed by uptake via glucose transporters [41].

PET-based techniques are readily implemented with good spatial resolution (1-2 $\mathrm{mm})$. A limitation of this approach is that it cannot measure absolute $\mathrm{pH}$, and only indicates regions below a certain $\mathrm{pH}_{\mathrm{e}}$ threshold. $\mathrm{pH}$ values can be estimated from arterial blood sampling and model fitting, but these values have not been correlated with microelectrode measurements.

\section{Experimental Cancer Models for the Study of Tumour pH Regulation}

To gain insight into tumour $\mathrm{pH}_{\mathrm{e}}$ regulation in vivo, imaging techniques have to be deployed on cancer models ranging from traditional monolayer cell cultures to mouse models and human patients. The measurement of tumour $\mathrm{pH}_{\mathrm{e}}$ becomes more challenging as the complexity and physiologic relevance of the model system increase.

Two-dimensional (2D) monolayer cell cultures have traditionally been the workhorse of cancer research, and most early studies on cancer $\mathrm{pH}$ regulation were done in this system. However, the extracellular environment within the monolayer cultures does not reflect the tumour microenvironment in vivo, not least because $\mathrm{H}^{+}, \mathrm{CO}_{2}$ and $\mathrm{HCO}_{3}{ }^{-}$can freely diffuse between the cells and the relatively huge volume of culture medium [42,43]. In contrast, the cancer cells in solid tumours co-exist in a disorganized tissue architecture with stromal fibroblast cells and various immune cells, all of which derive their blood supply from an abnormal tumour-associated vasculature [44]. The restricted diffusive capacity of $\mathrm{H}^{+}, \mathrm{CO}_{2}$ and $\mathrm{HCO}_{3}{ }^{-}$in the extracellular space of solid tumours [45] 
causes spatiotemporal heterogeneity of oxygenation and cellular metabolism, resulting in gradients of $\mathrm{pH}_{\mathrm{e}}$ that will not occur in 2D cell cultures.

In vitro 3D cell spheroid systems simulate some aspects of the spatial architecture and cell-to-cell contact found in solid tumours in vivo and provide a tractable platform to study the role of several cell physiological processes in regulating the tumour microenvironmental $\mathrm{pH}$ [43]. Spheroids are cell cultures in which cells are grown in clusters or aggregates, typically without the addition of the extracellular matrix or growth factors to the culture medium, or by growing cell clusters in low-attachment culture plates. Optical imaging by $\mathrm{pH}$-sensitive fluorescent dyes can be used to measure spatial gradients of $\mathrm{pH}_{\mathrm{i}}$ and $\mathrm{pH}_{\mathrm{e}}$ in these spheroid models.

More recently, the application of organoid technology from the field of stem cell research has led to the development of cancer organoids-microscopic self-organizing, 3D structures that recapitulate many of the structural and functional aspects of tumours in vivo [46]. The cancer cells are embedded in a 3D matrix such as a collagen or basement membrane, sometimes with the addition of growth factors that promote growth as a 3D structure. Such organoids can also be co-cultured with fibroblasts and immune cells, thus recreating something of the cellular heterogeneity found within solid tumours. These organoids are increasingly used in the study of tumour metabolism and $\mathrm{pH}$ regulation, and they present an improvement over tumour spheroids in modelling in vivo tumour physiology [47,48].

However, tumour $\mathrm{pH}$ regulation cannot be fully modelled in culture, even by using tumour spheroids and organoids. Cancer cells in solid tumours are genetically heterogeneous, and they co-exist with non-transformed stromal and immune cells within an unknown nutrient and $\mathrm{O}_{2}$ milieu, with further differences due to tumour stage and exposure to therapy. While in situ tumours within patients remain the gold standard for studying tumour $\mathrm{pH}_{\mathrm{e}}$, animal models allow studies of gene and protein function by analysing the phenotypes that arise after silencing or overexpressing particular genes. Animal models for studying cancer biology differ in their complexity and their degree of fidelity to human cancers [49]. They include genetically engineered mouse models (GEMMs) that develop tumours in situ, as well as allograft models and xenograft models derived from human tumours (patient-derived xenografts) or cancer cell lines. These in vivo models come closer to the physiological complexity of human cancers than cell culture preparations, and they also allow interactions between the tumour and normal host tissues. Nonetheless, the interpretation of the data from mouse models must have the caveat that factors such as diet, strain, sex, age, husbandry and environmental stressors can affect metabolism of the host animal, and thus the metabolism of the tumour [50,51]. Moreover, $\mathrm{pH}$ regulation studies in such model systems are restricted by the currently available imaging techniques, which have limited sensitivity, reproducibility and spatiotemporal resolution, and face challenges with the targeting and accessibility of $\mathrm{pH}$ probes.

\section{Why Is Tumour $\mathrm{pH}_{\mathrm{e}}$ Acidic?}

For many years, it was believed that the increased lactate metabolic flux and extrusion of this acidic metabolite from cancer cells explained tumour extracellular acidification. This simple model assumed that lactic acid exported from cancer cells into the interstitial fluid accumulates because it cannot be transported away rapidly enough to the blood vasculature, and that acidification ensues because of the poor buffering capacity of the extracellular fluid.

Early evidence to challenge this concept came from a series of studies by Tannock and colleagues in the 1990s, which found that tumours derived from glycolysis-deficient Chinese Hamster fibroblasts, that lacked both the phosphoglucose isomerase enzyme and a number of glucose transporters, surprisingly had an acidic $\mathrm{pH}_{\mathrm{e}}$ in vivo, even though negligible amounts of lactic acid were formed and these cells were not able to acidify the culture media in vitro [52]. This finding was replicated using Chinese Hamster ovary cells lacking lactate dehydrogenase, which also showed minimal lactic acid production in vitro but were nonetheless capable of producing tumours with acidic $\mathrm{pH}_{\mathrm{e}}$ when transplanted in vivo [53]. One possible explanation for this unexpected result would be that these mutant cells produced large amounts of $\mathrm{CO}_{2}$ by oxidative metabolism. In fact, earlier studies by Gullino et al., 
sampling interstitial fluid from solid tumours grown in 'Gullino' PTFE chambers, showed that the tumour interstitial fluid of numerous tumour types contained high levels of $\mathrm{CO}_{2}$ [54].

Numerous studies on cancer metabolism over the past decade have revealed that cancer cells exhibit aerobic glycolysis due to the activation of oncogenes, the loss of tumour suppressor genes, and the upregulation of the PI3K pathway, and that one advantage of these high glycolytic rates is the availability of precursors for anabolic pathways, that are needed for the biosynthesis of cellular building blocks during proliferation $[55,56]$. While this Warburg effect has been observed in many human cancers (and is indeed the basis by which FDG-PET scans operate), studies have demonstrated that human cancers show distinct metabolic heterogeneity [57] and produce most of their metabolic energy through glucose oxidation via the tricarboxylic acid cycle, resulting in the formation of $\mathrm{CO}_{2}$ [58-60].

By sampling the blood entering and exiting solid tumours in vivo, it is possible to calculate their outputs of lactic acid and of $\mathrm{CO}_{2}$. Such calculations have been performed on both animal models and tumours in patients, and they have found that the tumour $\mathrm{CO}_{2}$ output is comparable to or greater than that of lactate. Kallinowksi et al. studied a tumour xenograft model in which human tumour xenografts were grown in nude rats, on pedicles containing the epigastric artery and vein, and were prevented from acquiring other vasculature by polyethylene sheaths $[61,62]$. This defined blood supply allowed measurement of the blood flow and assay of metabolite concentrations from the artery supplying and the veins draining the tumour. Holm et al. performed similar balance studies on human colon carcinomas during bowel resection surgery, by cannulating the mesenteric vessels supplying these tumours and measuring the metabolites in blood from the mesenteric artery and vein [63]. Calculations of the production of $\mathrm{CO}_{2}$ from the substrate balance data reported by Kallinowski et al. found that human xenografts in nude rats produced $588-850 \mathrm{nmol} / \mathrm{g} / \mathrm{min} \mathrm{CO}_{2} \mathrm{vs.} 527 \mathrm{nmol} / \mathrm{g} / \mathrm{min}$ lactate, and similar calculations from the data in Holm et al. found that colonic tumours in human patients produced five times more $\mathrm{CO}_{2}$ than lactate, $1296 \mathrm{nmol} / \mathrm{g} / \mathrm{min} \mathrm{CO}_{2}$ vs. $220 \mathrm{nmol} / \mathrm{g} / \mathrm{min}$ lactate [64]. These balance studies suggested that solid tumours in vivo synthesised most of their ATP by oxidative metabolism (because the complete oxidation of glucose to $\mathrm{CO}_{2}$ phosphorylates 16 times the amount of ATP obtained from glycolysis to lactate [65]), and they did not support the dogma that cancer cells rely on aerobic glycolysis for their energetic requirements or that tumour extracellular acidification is entirely due to lactate extrusion.

However, although these in vivo studies suggest that $\mathrm{CO}_{2}$ will be a significant source of metabolic acid production in cancer cells, the higher $\mathrm{pK}$ of carbonic acid (pKa 6.35) compared to that of lactic acid (pKa 3.86) means that, on a mole for mole basis, $\mathrm{CO}_{2}$ would have a much smaller acidifying effect than lactic acid. This suggests that in order for $\mathrm{CO}_{2}$ to be a significant source of acidity in the tumour extracellular space, there must be an additional mechanism in play, such as one to accelerate the hydration of $\mathrm{CO}_{2}$ to form $\mathrm{H}^{+}$. In the next section of this review, we explore how CAIX provides such an additional mechanism and thus maximises the locally acidifying effect of $\mathrm{CO}_{2}$ production.

\section{Carbonic Anhydrase IX and Its Role in Cancer Biology}

The role of the enzyme CAIX is central to understanding how $\mathrm{CO}_{2}$ production leads to the acidification of the tumour interstitial space. CAIX belongs to a family of zinc metalloprotein enzymes that catalyse the reversible interconversion of $\mathrm{CO}_{2}$ to form $\mathrm{HCO}_{3}{ }^{-}$and $\mathrm{H}^{+}$[66]. In mammals, there are 16 isoforms of carbonic anhydrases, which differ in their activity and cellular localization [67]. Cancer cells primarily express the plasma membrane-associated carbonic anhydrases, CAIX and CAXII [68-70], as well as intracellular carbonic anhydrases such as CAI [71,72] and CAII [73-75]. CAIX has been extensively studied as a potential therapeutic target in oncology, owing to its specificity to cancer cells-it has a very restricted expression in the normal stomach and gut epithelial cells [76] but is strongly upregulated in many different types of tumour tissue [77]. Several preclinical studies have suggested that the inhibition of the CAIX function delays the growth of tumours [78-80] and reduces invasion and metastasis under experimental conditions [79]. 
CAIX is a protein that is tethered to the cell surface membrane. It is comprised of an extracellularly facing catalytic domain, an N-terminal proteoglycan-like (PG) domain, a single transmembrane domain and a short intracellular C-terminal tail [70]. The N-terminal PG domain is unique to CAIX within the CA family [81] and has been shown to be important in the assembly of focal adhesion contacts during cell migration [82,83], and as a buffer for protons to support the catalytic activity of the enzyme [84]. Recent studies have also suggested that this PG domain may serve as a proton antenna for monocarboxylate transporters, to facilitate proton-coupled lactate flux [85].

The regulation of CAIX expression has been linked not only to the hypoxic tumour microenvironment, but also to genetic mutations, and dysregulated growth factor signalling pathways. In hypoxia, CAIX expression is mainly upregulated by the stabilization of the hypoxia inducible transcription factors (HIF) and the activation of the HIF signalling pathway. The HIF signalling pathway has been extensively reviewed elsewhere [86,87]. Briefly, HIF-1 is a heterodimeric transcription factor that is composed of an $\mathrm{O}_{2}$-regulated HIF- $1 \alpha$ subunit and a constitutively expressed HIF- $\beta$ subunit [88]. In the presence of oxygen, the tumour suppressor von Hippel-Lindau (pVHL) protein targets HIF-1 $\alpha$ for proteasomal degradation by means of proline hydroxylation using $\mathrm{O}_{2}$ and $\alpha$-ketoglutarate as substrates [89]. Most notable amongst the HIF target genes are the vascular endothelial growth factor (VEGF) [90], carbonic anhydrase 9 (CA9) [68], and components of metabolic pathways such as lactate dehydrogenase-A (LDHA) [91] and glucose transporters (GLUT1) [92,93]. Of these, CA9, the gene encoding CAIX, is one of most responsive genes to hypoxia because the hypoxia response element (HRE) sequence of this gene is localized just upstream of the transcription initiation site [94]. Due to the tight regulation by HIF-1, CAIX is predominantly expressed in regions of chronic hypoxia within solid tumours [68].

Mutations and dysregulated signalling pathways in cancers have been mechanistically linked to the regulation of CAIX expression via hypoxia-independent activation of HIF. The most notable example would be the inactivation mutations of the von Hippel-Lindau tumour suppressor $(V H L)$ gene which lead to the constitutive activation of HIF signalling and CAIX expression in clear cell renal cell cancers (ccRCCs) and the von Hippel-Lindau syndrome hemangioblastomas [95,96]. Besides this, HIF-1 $\alpha$ expression and signalling are also regulated by major signal transduction pathways, including those that involve phosphatidylinositol 3-kinase (PI3K) [97] and extracellular signal-regulated kinase $($ ERK)/mitogen-activated protein kinase (MAPK) $[98,99]$ and upstream tyrosine kinases such as SRC and RET [100,101]. Mutations in other tumour suppressor genes such as PTEN, PML and TSC activate HIF by promoting its translation [102-104]. Less common activators of HIF are mutations in the Krebs cycle enzymes, fumarate hydratase and succinate dehydrogenase [105-107], where the resulting increased levels of fumarate or succinate act as 2-oxoglutarate analogues to inhibit pVHL prolyl hydroxylation, thereby activating HIF signalling $[108,109]$.

CAIX is expressed in a wide variety of solid tumours, including breast [110,111], colorectal [112], glioblastoma [113], lung [114], head and neck [115,116], and cervical cancers [117]; its expression is typically associated with poor disease prognosis [110-117]. The correlation between CAIX expression and poor prognosis can be mechanistically explained by CAIX protecting the cancer cell from intracellular acidosis, allowing rapid tumour growth, and creating extracellular acidosis, which promotes cancer cell migration and invasion. Both catalytic and non-catalytic CAIX-associated mechanisms allow cancer cells to progress along the invasion-metastasis cascade and thus to seed distant metastatic outgrowths [83,118-120].

CAIX expression has been shown to have an important role in the regulation and maintenance of cancer stem cells (CSCs), a small but distinct subpopulation of cancer cells within a solid tumour that are capable of regenerating the tumour. CSCs exhibit many of the properties of stem cells including clonogenicity, self-renewal, quiescence, and the ability to undergo epithelial-to-mesenchymal transition (EMT) [121,122]. In addition, CSCs have been shown to preferentially survive within hypoxic niches $[123,124]$. In the first study to report a link between CAIX and cancer stem cells, Lock et al. demonstrated that CAIX expression is required for the enrichment and function of breast 
CSCs in hypoxia, and that CAIX is required for mTOR signalling under hypoxia [125]. Intriguingly, CAIX expression was found to regulate the expression of 'stemness' genes such as Snail and Notch, and genes involved in the EMT; additionally, the inhibition of CAIX by small-molecule inhibitors depleted CSCs from tumours in vivo, reducing tumour growth and metastasis in preclinical models of cancer [125]. Ledaki et al. showed that subpopulations of cancer cells with hypoxia-inducible CAIX expression are enriched with cells that show high self-renewal capacity and express cancer stem cell markers. They also showed that the differential induction of CAIX under hypoxia is due to epigenetic regulation which induces differences in chromatin structure [126]. While these studies suggest that CAIX may be an important therapeutic target for selectively depleting CSCs, it remains unknown whether the effect of CAIX in CSCs is mediated through its role as a regulator of tumour $\mathrm{pH}_{\mathrm{e}}$.

CAIX catalyses the reversible hydration of $\mathrm{CO}_{2}$ at its exofacial site on the cell surface membrane, thereby placing it in a central position to regulate tumour $\mathrm{pH}_{\mathrm{e}}$, and indirectly, $\mathrm{pH}_{\mathrm{i}}$ (Figure 1). To study the effect of CAIX on $\mathrm{pH}_{\mathrm{e}}$ and $\mathrm{pH}_{\mathrm{i}}$, Swietach et al. employed confocal imaging using fluorescent $\mathrm{pH}$ dyes on 3D spheroid models of RT112 renal cancer cells [127] and HCT116 colorectal cancer cells [45], both of which overexpress CAIX. CAIX overexpression intensified the core-to-periphery $\mathrm{pH}_{\mathrm{i}}$ and $\mathrm{pH}_{\mathrm{e}}$ gradients of the spheroids, rendering the $\mathrm{pH}_{\mathrm{i}}$ of cells at the core less acidic, but making the peripheral $\mathrm{pH}_{\mathrm{e}}$ more acidic $[45,127]$. By the computational modelling of the data from their spheroid studies, they showed that CAIX maintains a steep outward-directed $\mathrm{CO}_{2}$ gradient across the plasma membrane, accelerating the $\mathrm{CO}_{2}$ excretion, and that this results in extracellular acidification and a more alkaline $\mathrm{pH}_{\mathrm{i}}$ [45]. Mathematical modelling of this reaction in vivo suggested that the hydration of $\mathrm{CO}_{2}$ at the extracellular surface of the cell membrane also allows the parallel diffusion of $\mathrm{CO}_{2}, \mathrm{HCO}_{3}{ }^{-}$and $\mathrm{H}^{+}$ across the interstitial space into the nearest blood vessel [45]. CAIX was predicted to exert an effect on the $\mathrm{pH}_{\mathrm{i}}$ and $\mathrm{pH}_{\mathrm{e}}$ in poorly perfused but metabolically active tissues, with the extracellular $\mathrm{CO}_{2} / \mathrm{HCO}_{3}{ }^{-}$ buffer system driven out of equilibrium [45]. The effect of CAIX on $\mathrm{pH}_{\mathrm{e}}$ will depend on the type of acid released across the cell membrane, and the greatest acidifying effect would be observed if the cell metabolized glucose completely to $\mathrm{CO}_{2}$ [45]. In contrast, the greatest alkalinizing effect would occur if all the glucose was metabolized into lactic acid, without any neutralisation of the lactic acid by the $\mathrm{HCO}_{3}{ }^{-}$to form lactate ${ }^{-}$and $\mathrm{H}^{+}$[45].

Hypoxic cancer cells display CAIX on their extracellular membrane but also have intracellular carbonic anhydrases such as CAII. This would allow them to extrude the $\mathrm{H}^{+}$that is formed by the dissociation of the lactic acid product of anaerobic glycolysis, by using a Jacobs-Stewart Cycle (Figure 2) [128]. Bicarbonate, formed by the mechanism shown in Figure 1, is transported by the $\mathrm{Na}^{+} / \mathrm{HCO}_{3}{ }^{-}$cotransporter into the hypoxic cell, where, under catalysis by CAII, it binds to $\mathrm{H}^{+}$, forming $\mathrm{CO}_{2}$ and $\mathrm{H}_{2} \mathrm{O}$. The $\mathrm{CO}_{2}$ then diffuses through the cell membrane into the extracellular space where CAIX on the extracellular surface catalyses its hydration to $\mathrm{HCO}_{3}{ }^{-}$and $\mathrm{H}^{+}$; thus, an equivalent amount of $\mathrm{H}^{+}$that was originally in the hypoxic cell is now in the extracellular fluid. Excess $\mathrm{CO}_{2}$ from the cancer tissue will diffuse to host capillaries. 


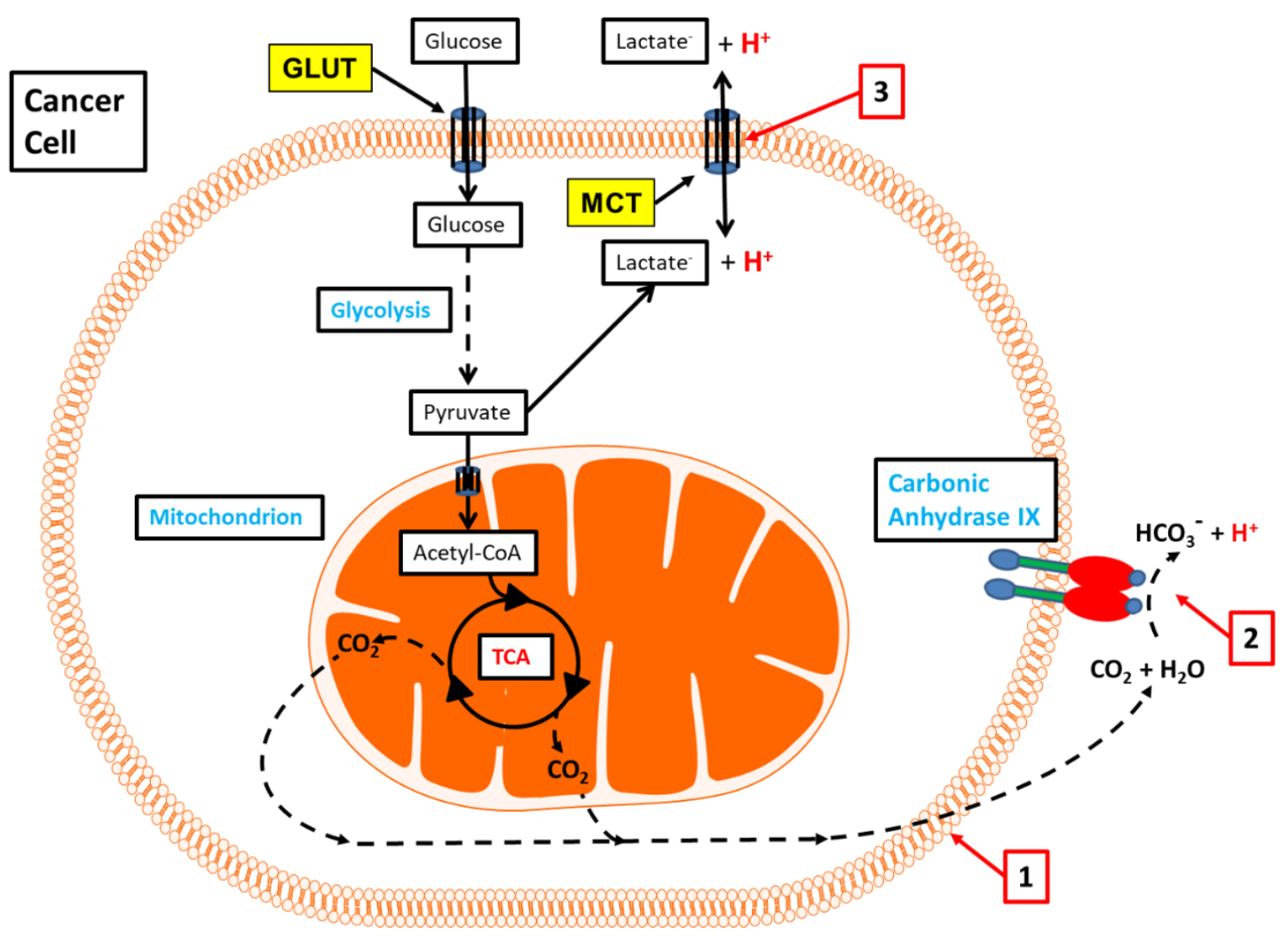

Figure 1. Carbonic anhydrase IX (CAIX) links tumour energy metabolism to its $\mathrm{pH}$ regulation. 1. The major by-product of oxidative energy metabolism, $\mathrm{CO}_{2}$ diffuses across the cell membrane lipid bilayer into the extracellular space, along its concentration gradient; 2 . On the extracellular surface of the cell membrane, the exofacial catalytic domain of CAIX catalyses the hydration of $\mathrm{CO}_{2}$ to form $\mathrm{H}^{+}$and $\mathrm{HCO}_{3}{ }^{-}$; 3. In parallel, lactate, the end-product of glycolysis, exits the cell through the monocarboxylate transporter at a rate that is influenced by the $\mathrm{pH}$ gradient across the cell membrane $\left(\mathrm{pH}_{\mathrm{i}}-\mathrm{pH}_{\mathrm{e}}\right.$ gradient). GLUT, glucose transporter; $\mathrm{MCT}$, monocarboxylate transporter. 


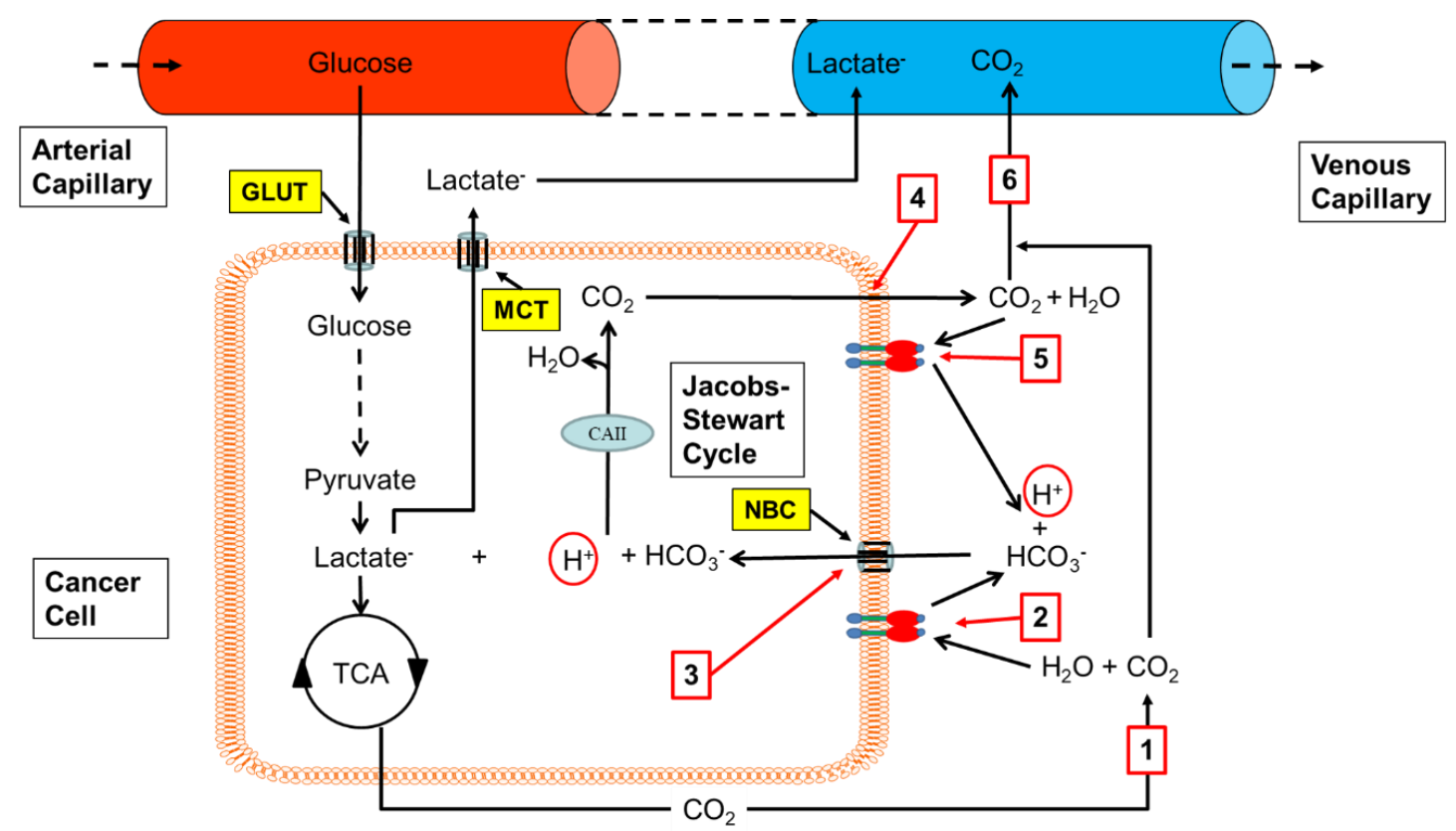

Figure 2. A Jacobs-Stewart Cycle helps hypoxic cancer cells extrude $\mathrm{H}^{+}$produced by anaerobic glycolysis. 1. $\mathrm{CO}_{2}$ diffuses from the cancer cell into the extracellular space; 2 . CAIX on the extracellular surface of the hypoxic cancer cell catalyses the hydration of $\mathrm{CO}_{2}$ to form $\mathrm{H}^{+}$and $\mathrm{HCO}_{3}{ }^{-}$; 3 . The $\mathrm{HCO}_{3}{ }^{-}$ enters the hypoxic cancer cell via the $\mathrm{Na}^{+} / \mathrm{HCO}_{3}{ }^{-}$cotransporter and binds $\mathrm{H}^{+}$from lactic acid, catalysed by CAII, thus forming $\mathrm{CO}_{2} ; 4$. The $\mathrm{CO}_{2}$ diffuses from the hypoxic cancer cell into the extracellular space, along its concentration gradient; 5 . On the extracellular surface of the hypoxic cancer cell, CAIX catalyses the hydration of the $\mathrm{CO}_{2}$ to form $\mathrm{H}^{+}$and $\mathrm{HCO}_{3}{ }^{-}$. The $\mathrm{HCO}_{3}{ }^{-}$provides further substrate to repeat stage 3 of the cycle, and an equivalent amount of $\mathrm{H}^{+}$that was originally inside the hypoxic cancer cell (ringed in red) is now in the extracellular fluid; 6. Accumulating $\mathrm{CO}_{2}$ diffuses to a capillary. GLUT, glucose transporter; $\mathrm{MCT}$, monocarboxylate transporter; $\mathrm{NBC}, \mathrm{Na}^{+} / \mathrm{HCO}_{3}{ }^{-}$cotransporter.

\section{Discovery of the Tumour Extracellular pH-Stat Mechanism}

Stubbs et al. previously proposed that the acidic tumour $\mathrm{pH}_{\mathrm{e}}$ reflects more than just the high acid output of the cancer cells, and postulated the existence of an extracellular $\mathrm{pH}$ homeostatic mechanism, a $\mathrm{pH}_{\mathrm{e}}$-stat, that was subverted by the cancer cell to set the $\mathrm{pH}_{\mathrm{e}}$ at a constant level and curtail excessive $\mathrm{pH}$ loading [129]. While an acidic tumour $\mathrm{pH}_{\mathrm{e}}$ promotes tumour growth and invasion, the $\mathrm{pH}_{\mathrm{e}}$ cannot be allowed to fall too low, as over-acidification would cause cell necrosis. Hence, cancer cells must utilise this $\mathrm{pH}_{\mathrm{e}}$-stat to maintain a microenvironment that is hostile to the surrounding normal tissues, yet favourable for their own survival.

If $\mathrm{pH}_{\mathrm{e}}$ was indeed under homeostatic control, then it should not correlate with $\mathrm{pH}_{\mathrm{i}}$, whereas in a model of $\mathrm{H}^{+}$transport, in which the rate of the $\mathrm{H}^{+}$efflux from the cells depends only on the proton concentration in the interstitial space, there should be a tendency for $\mathrm{pH}_{\mathrm{i}}$ and $\mathrm{pH}_{\mathrm{e}}$ to be correlated. Using ${ }^{31} \mathrm{P}$ MRS and the extracellular $\mathrm{pH}$ probe 3-APP, Stubbs et al. measured $\mathrm{pH}_{\mathrm{i}}$ and $\mathrm{pH}_{\mathrm{e}}$ in a range of rodent tumour models (RIF-1 fibrosarcoma, H9681a hepatoma and GH3 prolactinoma), and found no correlation between the $\mathrm{pH}_{\mathrm{i}}$ and $\mathrm{pH}_{\mathrm{e}}$ values [129]. These findings supported the hypothesis that the acidic tumour $\mathrm{pH}_{\mathrm{e}}$ is not simply a function of tumour metabolism per se, but is maintained by a homeostatic mechanism-a cancer $\mathrm{pH}_{\mathrm{e}}$-stat.

Several in vitro studies have suggested that the biochemical and biophysical properties of CAIX make it suited to the role of pHe-stat. In 2009, Alterio et al. published the first x-ray crystal structure of the catalytic domain of CAIX and showed that the presence of the proteoglycan chain at the border of the active site of the enzyme lowered its $\mathrm{pK}_{\mathrm{a}}$ from 7.01 to 6.49 , ensuring that the enzyme had better catalytic efficiency at the acidic $\mathrm{pH}$ values at which it operated [130]. Using ${ }^{18} \mathrm{O}$ exchange between 
$\mathrm{CO}_{2}$ and $\mathrm{H}_{2} \mathrm{O}$ to measure the exofacial CAIX activity in MDA-MB-231 breast cancer cells by membrane inlet mass spectrometry, $\mathrm{Li}$ et al. reported the first detailed measurement of the catalytic properties of the enzyme in its native membrane environment [131]. They found that the rate constant for the catalytic hydration reaction was faster than for the dehydration at the physiological $\mathrm{pH}$ of 7.4 [131]. At $\mathrm{pH}$ 6.8, the rate constants for hydration and dehydration were essentially equal, and at $\mathrm{pH}$ values lower than 6.8, the dehydration reaction was faster [131]. Mahon et al. reported that the catalytic domain of CAIX exhibits biochemical and biophysical properties that create low $\mathrm{pH}$ stability and activity [132]. Taken together, these findings suggest that the primary role of tumour CAIX is to utilize the interconversion of $\mathrm{CO}_{2}$ and $\mathrm{HCO}_{3}{ }^{-}$in order to stabilize the $\mathrm{pH}_{\mathrm{e}}$ around 6.8, thus maintaining an acidic $\mathrm{pH}_{\mathrm{e}}$ set-point of cancer cells in response to the proton load from cellular metabolism. Intriguingly, the measurement of CAIX activity in vitro in HCT116 cells showed that CA activity was markedly reduced by decreasing the $\mathrm{pH}$ over the $\mathrm{pH}$ range found in tumours, with a $\mathrm{pK}$ of 6.84 and a Hill cooperativity coefficient of 2 . This Hill coefficient would tend to sharpen the change in enzyme activity with $\mathrm{pH}_{\mathrm{e}}$, suggesting that $\mathrm{CAIX}$ may have been adapted to provide a $\mathrm{pH}_{\mathrm{e}}$-stat mechanism whereby excess acid self-limits the build-up of extracellular acid [80].

In parallel, several investigators have sought to study the effect of CAIX expression on tumour $\mathrm{pH}_{\mathrm{e}}$ in xenograft models, using various magnetic resonance-based $\mathrm{pH}_{\mathrm{e}}$ measurement techniques.

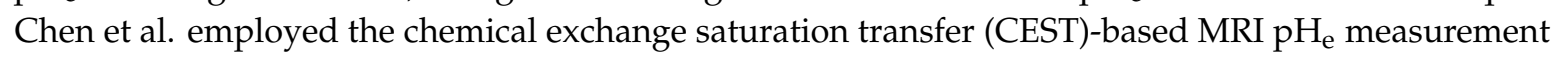
technique, acidoCEST MRI, to measure tumour $\mathrm{pH}_{\mathrm{e}}$ in a range of lymphoma xenograft tumour models (Raji, Ramos and Granta 519 cell lines) with different levels of CAIX expression [133]. The average tumour $\mathrm{pH}_{\mathrm{e}}$ ranged between 6.78 and 6.86, but there was no statistically significant difference between the mean $\mathrm{pH}_{\mathrm{e}}$ values of the different models. They derived a xenograft acidity score from the percentage and magnitude of the acidity, and found a correlation between that score and the level of CAIX expression in the tumour models, measured by histopathological staining [133]. Despite the positive correlation, it was not possible to draw any conclusion about causality between the levels of CAIX expression and the xenograft acidity score.

Using hyperpolarized ${ }^{13} \mathrm{C}$ magnetic resonance spectroscopy with $\left[{ }^{13} \mathrm{C}\right]$ bicarbonate $\left(\mathrm{H}^{13} \mathrm{CO}_{3}{ }^{-}\right)$, Gallagher et al. measured the $\mathrm{pH}_{\mathrm{e}}$ of two colorectal tumour xenograft models expressing different levels of CAIX [27]. However, while they observed a lowering of $\mathrm{pH}_{\mathrm{e}}$ in the CAIX-overexpressing tumours, the measured tumour pHe values were alkaline, likely an overestimation error due to the incomplete equilibration of the hyperpolarized ${ }^{13} \mathrm{C}$ label between the $\mathrm{H}^{13} \mathrm{CO}_{3}{ }^{-}$and ${ }^{13} \mathrm{CO}_{2}$ pools on the timescale of the ${ }^{13} \mathrm{C}$ MRS measurements. This problem arises because the accurate measurement of $\mathrm{pH}_{\mathrm{e}}$ using the hyperpolarized ${ }^{13} \mathrm{C}$ bicarbonate technique is dependent on the tissue having high levels of carbonic anhydrase activity [27]. Using ${ }^{13} \mathrm{C}$ MRS magnetization transfer to measure the rate of exchange of hyperpolarized ${ }^{13} \mathrm{C}$ label between bicarbonate and $\mathrm{CO}_{2}$, Gallagher et al. were able to measure the enzymatic activity of carbonic anhydrase in their tumour models and observed that, paradoxically, the tumours overexpressing CAIX showed a lower enzyme activity compared to the controls [27]. The administration of bicarbonate in the drinking water of mice elevated tumour $\mathrm{pH}_{\mathrm{e}}$ and restored enzyme activity to control levels, suggesting that the enzymatic activity of CAIX exhibits $\mathrm{pH}$ dependence and can be inhibited at low $\mathrm{pH}$ levels, akin to a negative feedback mechanism [27]. This observation suggests the interesting proposition that CAIX expression may be increased in hypoxia to compensate for the decreased specific activity of the enzyme at the lower $\mathrm{pH}_{\mathrm{e}}$.

To study the regulatory effect of CAIX on the tumour $\mathrm{pH}_{\mathrm{e}}$, Lee et al. employed a high-resolution in vivo $\mathrm{pH}$-imaging technique that was independent of the enzymatic kinetics of CAIX. Using ${ }^{1} \mathrm{H}$ MRSI with an extracellular $\mathrm{pH}^{1} \mathrm{H}$ MRS probe, ISUCA, they performed high-resolution spatial mapping of $\mathrm{pH}_{\mathrm{e}}$ in colorectal tumour xenograft models expressing different levels of CAIX, and observed that CAIX-expressing tumours had a more acidic $\mathrm{pH}_{\mathrm{e}}$ than the control tumours [134]. Importantly, the expression of CAIX imposed an upper limit of tumour $\mathrm{pH}_{\mathrm{e}}$ at 6.93, consistent with the hypothesis that CAIX acts as a $\mathrm{pH}$-stat to maintain the $\mathrm{pH}_{\mathrm{e}}$ at a more acidic level than the typical $\mathrm{pH}_{\mathrm{e}}$ of 7.35-7.45 [134]. Intriguingly, there was no difference in $\mathrm{pH}_{\mathrm{i}}$ values between the CAIX-expressing 
and non-CAIX expressing tumours, as measured by ${ }^{31} \mathrm{P}$ MRS, suggesting that CAIX acidifies only the tumour $\mathrm{pH}_{\mathrm{e}}$ and not $\mathrm{pH}_{\mathrm{i}}$ [101]. This latter observation was concordant with the earlier proposal of Stubbs et al. [129] that if $\mathrm{pH}_{\mathrm{e}}$ was indeed under homeostatic control, then it should not correlate with $\mathrm{pH}_{\mathrm{i}}$. Additionally, these CAIX-expressing tumours were found to have a higher level of lactate compared to the control tumours [134]. Calculations of the ratio of lactate on either side of the membrane from the mean $\mathrm{pH}_{\mathrm{i}}$ and $\mathrm{pH}_{\mathrm{e}}$ values of these tumours revealed that CAIX-expressing tumours had markedly higher intracellular lactate than non-CAIX expressing control tumours [134]. Collectively, these findings suggest that CAIX acts as a $\mathrm{pH}$-stat that maintains an acidic tumour $\mathrm{pH}_{\mathrm{e}}$.

\section{Implications of an Extracellular pH-Stat for Cancer Progression}

It is now well established that the acidic tumour $\mathrm{pH}_{\mathrm{e}}$ phenotype is associated with aggressive behaviour of solid tumours. Thomlinson and Gray first reported that human tumours grew as cords around blood vessels, and that as a tumour grows and outstrips its blood supply, its central region becomes hypoxic, although the cells remain within the diffusion distance of glucose [135]. Hypoxia upregulates glycolysis through the activation of hypoxia-inducible factor-1 (HIF-1) which induces the expression of glycolytic enzymes (e.g., lactate dehydrogenase A) [136], proton-exporting active transporters, (e.g., monocarboxylate transporter 4 (MCT4) [137]), and carbonic anhydrase IX (CAIX) [68].

These adaptations, which enable cancer cells to survive hypoxia by maintaining their intracellular $\mathrm{pH}$ within the physiological range and thereby creating an acidic $\mathrm{pH}_{\mathrm{e}}$, have also been found to promote their invasion into normal host tissue and metastasis into other organs. Setting $\mathrm{pH}_{\mathrm{e}}$ to a constant acidic condition may therefore be an evolutionary strategy used by cancer cells to create an environment that fosters tumour growth and invasion in response to microenvironmental selection forces. One could even argue that the characteristically hypoxic tumour microenvironment and the chaotic blood supply that gives rise to it are both evolutionarily selected features that are driven by the aggressive phenotype conferred on cancer cells by extracellular acidity.

Gatenby, Gillies and colleagues have shown that an acidic $\mathrm{pH}_{\mathrm{e}}$ promotes tumour local invasion and metastasis, and that cancer cells are able to modulate the set point of tumour $\mathrm{pH}_{\mathrm{e}}$ in response to microenvironmental selection pressures as an evolutionary strategy favouring invasion [21,138]. At the cellular level, migrating cancer cells have proton-exporting machinery, such as sodium-hydrogen exchangers (NHE1) or sodium-bicarbonate cotransporters (NBCn1), coupled to CAIX at the front of their invadopodia, resulting in a more acidic $\mathrm{pH}_{e}$ at the leading edge of the migrating cell $[83,119]$ which activates proteases, e.g., lysosomal cathepsins, that then degrade the host's extracellular matrix $[139,140]$. Gatenby et al. initially reported in silico mathematical simulations predicting that tumours acidified the extracellular space of normal tissue around the tumour edge [141], and confirmed these predictions via the intravital imaging of PC3N and MCF7 tumours, grown in dorsal window chambers [21]. They measured the peritumoural $\mathrm{H}^{+}$flow using vectors generated from $\mathrm{pH}_{\mathrm{e}}$ distribution around the tumours, and found a general flow of tumour-derived acid from the core to the periphery, and then into the surrounding normal tissue [21]. In another study using dorsal window chamber tumour models and the confocal imaging of $\mathrm{pH}_{\mathrm{e}}$ with a fluorescent $\mathrm{pH}$ indicator, SNARF-1 Free Acid, they observed that the acidic $\mathrm{pH}_{\mathrm{e}}$ of peritumoural tissues was coincident with the location of subsequent tumour invasion, confirming a specific prediction of the acid-mediated invasion hypothesis [22]. The treatment of the animals with sodium bicarbonate reduced the $\mathrm{pH}$ gradient and reduced the local invasion in these tumour models [22]. Using a theoretical framework from evolutionary dynamics, Gatenby and Gillies proposed that the metabolic properties of cancer cells and their consequent interstitial acidification provided an evolutionary advantage that promotes tumour cell proliferation at the expense of the surrounding normal cells [142].

Further support for the acid-mediated invasion hypothesis has come from histopathological data showing cells at the invading edge expressing significantly more CAIX than those in the core of the tumour. Using quantitative image analysis of histologic specimens from patients with breast cancers, 
Lloyd et al. found that the spatial distribution of CAIX was consistently higher in the invasive tumour edge compared to the centre in all samples, which matched the predictions of evolutionary game theory models [143]. A key assumption of their model was that CAIX was able to set the $\mathrm{pH}_{\mathrm{e}}$ at 6.8 and that it served as a biomarker of regional tumour acidity. Thus, cancer cells are predicted to evolve towards an evolutionarily stable state, dictated by their adaptations to changes in environmental conditions such as blood flow and hypoxia [143]. Collectively, these studies suggest that the acidic $\mathrm{pH}_{\mathrm{e}}$ confers a selective advantage during the somatic evolution of cancers by facilitating the invasion of cancer cells into surrounding normal tissues.

\section{CAIX as a Therapeutic Target in Oncology}

CAIX is a promising therapeutic target in oncology. In vivo studies have shown that the genetic ablation of CAIX reduced the growth rate of colon and breast cancer tumour xenografts. Using a tetracycline-inducible system for RNA-interference, Chiche et al. reported that silencing the ca9 gene reduced colorectal LS174Tr xenograft tumour volume by up to $40 \%$, and that this also resulted in a compensatory upregulation of ca12 mRNA [78]. Consequently, the greatest reduction in tumour volume was achieved through silencing both ca9 and ca12 genes. In cultured cells challenged with a $\mathrm{CO}_{2}$ load, both CAIX and CAXII contribute to extracellular acidification and the maintenance of a more alkaline resting $\mathrm{pH}_{\mathrm{i}}$ [78]. In a $4 \mathrm{~T} 1$ murine metastatic breast cancer model and an MDA-MB-231 human breast xenograft model, Luo et al. reported that shRNA-mediated the silencing of CAIX-attenuated tumour growth; it also inhibited spontaneous lung metastasis formation in the 4T1 model [78]. The effect on tumour growth and metastasis formation was recapitulated through the use of CAIX-specific small molecule inhibitors, confirming the efficacy of CAIX as a targetable biomarker for cancer therapeutics [78].

Another avenue for the use of CAIX inhibition may be as a combination therapy with antiangiogenic drugs; this could produce additive results, since immunohistochemical data show that CAIX is part of a resistance mechanism that enables tumours to adapt to the increased hypoxia induced by bevacizumab treatment [80]. McIntyre et al. reported that the shRNA knockdown of CAIX in colon cancer HCT116 and U87 glioblastoma xenografts enhanced the effect of antiangiogenic therapy with bevacizumab, resulting in a reduced tumour growth rate in vivo [80]. They also used acetazolamide to inhibit the enzymatic activity of CAIX, which recapitulated the effects of a combination of CAIX knockdown and bevacizumab. Like Chiche et al., they found that CAIX knockdown induced the expression of CAXII in 3D spheroids, but not in 2D cell culture [80]. In spheroid culture and tumour xenografts, CAIX expression was found to increase the growth rate and the expression of Ki-67, a marker of proliferation, while at the same time promoting necrosis and apoptosis [80].

\section{CAIX-Clinical Translation}

There is now convincing evidence that CAIX can serve as a biomarker and/or therapeutic target in various tumour types. To this end, a distinction can be drawn between the tumours that express CAIX as a consequence of inactivating mutations of the von Hippel-Lindau (pVHL) tumour suppressor protein, and tumours in which CAIX is present due to microenvironmental hypoxia. In the former group, exemplified by clear cell renal cell carcinoma (ccRCC), more than $90 \%$ of tumours with inactivating mutations of $\mathrm{pVHL}$ have a constitutive stabilization of HIF and a high percentage of tumour cells expressing CAIX [144,145]. In more advanced ccRCC, CAIX expression decreases due to a switch from the HIF-1 to the HIF-2 isoform, which explains why the low expression of CAIX (defined as staining fewer than $85 \%$ of cells) in such tumours is a marker of poor prognosis [146].

In many other tumour types, such as head and neck, breast, colorectal, brain and lung tumours, CAIX is expressed in areas that are hypoxic and/or acidic, and its expression usually increases with increasing tumour stage and grade [68]. Immunohistochemical staining of CAIX is mostly found at the plasma membrane, and while cytoplasmic and/or nuclear staining are also occasionally seen, their biological significance is unclear. In addition, CAIX expression is associated with various other 
prognostic variables including c-ErbB2/Her2 [147,148], EGFR [114,149], MMP-9 [149], CD44 [150] and Ki-67 [151]. CAIX can also be detected in tumour stroma, which is associated with poor prognosis [152]. As a consequence of ectodomain shedding and release in exosomes, CAIX can be detected in the body fluids of cancer patients, and this can be exploited for non-invasive screening or monitoring tumour response to therapy $[153,154]$.

Patients with tumours highly expressing CAIX are at a higher risk of disease progression and metastasis, independent of the tumour type or site. In a meta-analysis of studies between 2001-2015 involving more than 24,000 patients with non-RCC tumours, there was a strongly significant association between immunohistochemical CAIX staining and several different endpoints, including overall survival, disease-free survival, locoregional control, disease-specific survival, metastasis-free survival, and progression-free survival [155]. Besides this, numerous studies have reported the correlation between CAIX expression and resistance to chemotherapy [156], radiotherapy [115,157] and immunotherapies against PD-1 [158]. These findings provide a rationale for developing prognostic biomarkers and therapeutics based on CAIX expression.

Inhibitors of carbonic anhydrase activity as emerging anticancer therapeutics have been reviewed elsewhere [159]. In general, therapeutic strategies targeting CAIX involve one of two approaches. The first is based on the role of CAIX in $\mathrm{pH}$ regulation and uses compounds that inhibit its enzymatic activity through binding at or near its active site. The efficacy of this approach has been demonstrated by several preclinical studies in murine models of cancer [78-80]. Recently, SLC-0111, a small molecule inhibitor of CAIX, successfully completed Phase I clinical trials for the treatment of advanced, metastatic solid tumours [160]. Efforts are also underway to recruit patients for a Phase $1 \mathrm{~b}$ trial of SLC-0111 in combination with gemcitabine in metastatic pancreatic cancer [161]. However, the clinical use of single agent CAIX inhibitors is likely to be hindered by the cancer cell, inducing compensatory mechanisms such as the upregulation of CAXII expression, or other acid-extruding mechanisms such as NHE1, resulting in an unsatisfactory therapeutic effect. Therefore, a more prudent approach would be to explore the use of anti-CAIX therapy in conjunction with other established anti-cancer drugs. One example of this concept would be to use anti-CAIX therapy in patients undergoing anti-VEGF therapy, since CAIX expression is upregulated as a compensatory mechanism in tumours experiencing hypoxia as a result of anti-angiogenesis [80,162]. Besides this, CAIX inhibition can also be used in conjunction with radiotherapy, which has been demonstrated by the use of DH348, a nitroimidazole-based anti-CAIX inhibitor that not only reduced tumour growth in mice but also sensitized the tumours to radiotherapy [163].

The second strategy targets CAIX by immunotherapy and exploits the tumour-associated expression pattern of CAIX. The use of monoclonal antibodies against CAIX ensures high specificity and selectivity that are superior to the effects of chemical inhibitors, and the quick cell-killing effect of antibody-dependent cellular cytotoxicity (ADCC) circumvents the development of compensatory mechanisms. Most of the studies using this strategy have been undertaken in animal models of RCC and in patients with non-metastatic RCC, using the chimeric human-mouse monoclonal antibody G250 (RENCAREX/GIRENTUXIMAB), which is a safe, well tolerated antibody that was found to prolong disease-free survival by up to 22 months in a subgroup of ccRCC patients with high tumour CAIX expression [164].

In non-RCC tumours, CAIX expression is less frequent and more heterogeneous, thus it may not be such an attractive target for immunotherapy. However, the association between CAIX and metastasis makes it a plausible target as an adjuvant for metastasis-targeted immunotherapy. Since tumour cells residing in hypoxic and acidic regions are associated with therapy resistance, it is conceivable that these cells will express CAIX and that they will survive chemotherapy and/or radiotherapy and seed metastatic outgrowths. While targeting CAIX in such cells is certainly an intriguing prospect, there are only a few reported studies on the detection of CAIX in metastatic lesions [165-167], therefore more evidence is needed to support this hypothesis. 
Our understanding of the function of CAIX in tumour $\mathrm{pH}_{\mathrm{e}}$ regulation has highlighted the importance of mitochondrial energy metabolism in cancer. In parallel, several studies have suggested that mitochondrial metabolism plays an important role in the development of drug resistance in cancer $[168,169]$. It has been argued that resistant cancer cells are more dependent on mitochondrial oxidative metabolism than glycolysis. In many haematological and solid tumours, treatment resistance is associated with a shift towards an oxidative phosphorylation-dependent energetic status [60,170-172]. Resistant cells display higher levels of reactive oxygen species (ROS) and increased mitochondrial mass, oxygen consumption, ATP production and fatty acid synthesis [173-175]. This metabolic adaptation has been hypothesized as a strategy to meet the increased energetic demands of DNA repair, drug efflux and detoxification. Furthermore, the inhibition of oxidative phosphorylation has been shown to abrogate resistance to EGFR inhibitors in EGFR-driven lung cancers [176], docetaxel in prostate cancer [177], MAPK inhibitors in melanoma [178] and 5-fluorouracil (5FU) in colon cancers [179]. Therefore, combining conventional chemotherapies with mitochondrial inhibitors (e.g., metformin, tigecycline) represents a promising strategy [180]. In the context of CAIX and tumour $\mathrm{pH}_{\mathrm{e}}$ regulation, it is tempting to speculate that the inhibition of mitochondrial respiration may reduce the acidifying effect of CAIX on $\mathrm{pH}_{\mathrm{e}}$.

\section{Conclusions}

Our understanding of tumour $\mathrm{pH}$ and its regulation has come a long way, since the landmark discoveries of cancer cell metabolism by Otto Warburg, and the first in vivo measurements of tumour intracellular and extracellular $\mathrm{pH}$ in solid tumours. The progress in recent decades in the fields of cancer modelling, molecular biology, genetics, and in vivo imaging techniques has provided us with a molecular-level understanding of acid-base homeostasis in cancer. Since its discovery in the early 1990s, CAIX has emerged as an important $\mathrm{pH}$ regulator in solid tumours, with recent evidence demonstrating that it functions as a $\mathrm{pH}_{\mathrm{e}}$-stat. With increasing knowledge about the contribution of acidic $\mathrm{pH}_{\mathrm{e}}$ to all steps of cancer development and progression, it is now evident that CAIX provides a selective advantage to cancer cells by allowing them to create a hostile acidic environment in which they can survive and thrive, but in which host cells cannot, and to acquire an invasive and metastatic phenotype. The fact that CAIX-expressing cancer cells generally represent the most aggressive fraction of solid tumours indicates a fertile avenue for clinical translation in terms of diagnosis, prognosis, and therapy. It is unlikely, however, that targeting CAIX on its own will be sufficient to produce a meaningful clinical benefit because of the phenotypic plasticity and redundancies in cellular $\mathrm{pH}$ regulatory mechanisms. Probably, therefore, the greatest benefit of agents targeting CAIX would be realized by using them in combination with other therapeutic agents in an adjuvant or neoadjuvant setting.

Author Contributions: S.-H.L. and J.R.G. wrote the paper. All authors have read and agreed to the published version of the manuscript.

Funding: This research received no external funding.

Conflicts of Interest: The authors declare no conflict of interest.

\section{References}

1. Warburg, O.; Dickens, F.; Wilhelm, K. The Metabolism of Tumours: Investigations from the Kaiser Wilhelm Institute for Biology, Berlin-Dahlem; Arnold Constable: London, UK, 1930.

2. Griffiths, J.R. Are cancer cells acidic? Br. J. Cancer 1991, 64, 425-427. [CrossRef]

3. Griffiths, J.R.; McIntyre, D.J.; Howe, F.A.; Stubbs, M. Why are cancers acidic? A carrier-mediated diffusion model for H+ transport in the interstitial fluid. Novartis Found. Symp. 2001, 240, 46-62, discussion 62-67, 152-153.

4. Griffiths, J.R.; Stevens, A.N.; Iles, R.A.; Gordon, R.E.; Shaw, D. 31P-NMR investigation of solid tumours in the living rat. Biosci. Rep. 1981, 1, 319-325. [CrossRef] 
5. Griffiths, J.R.; Cady, E.; Edwards, R.H.T.; Mccready, V.R.; Wilkie, D.R.; Wiltshaw, E. 31P-NMR studies of a human tumour in situ. Lancet 1983, 321, 1435-1436. [CrossRef]

6. Evanochko, W.T.; Ng, T.C.; Glickson, J.D.; Durant, J.R.; Corbett, T.H. Human tumors as examined by in vivo 31P NMR in athymic mice. Biochem. Biophys. Res. Commun. 1982, 109, 1346-1352. [CrossRef]

7. Gillies, R.J.; Liu, Z.; Bhujwalla, Z. 31P-MRS measurements of extracellular pH of tumors using 3-aminopropylphosphonate. Am. J. Physiol. 1994, 267, C195-C203. [CrossRef]

8. García-Martín, M.L.; Hérigault, G.; Rémy, C.; Farion, R.; Ballesteros, P.; Coles, J.A.; Cerdán, S.; Ziegler, A. Mapping extracellular $\mathrm{pH}$ in rat brain gliomas in vivo by ${ }^{1} \mathrm{H}$ magnetic resonance spectroscopic imaging: Comparison with maps of metabolites. Cancer Res. 2001, 61, 6524-6531.

9. Provent, P.; Benito, M.; Hiba, B.; Farion, R.; López-Larrubia, P.; Ballesteros, P.; Rémy, C.; Segebarth, C.; Cerdán, S.; Coles, J.; et al. Serial in vivo spectroscopic nuclear magnetic resonance imaging of lactate and extracellular $\mathrm{pH}$ in rat gliomas shows redistribution of protons away from sites of glycolysis. Cancer Res. 2007, 67, 7638-7645. [CrossRef]

10. Corbet, C.; Feron, O. Tumour acidosis: From the passenger to the driver's seat. Nat. Rev. Cancer 2017, 17, 577-593. [CrossRef]

11. Thews, O.; Riemann, A. Tumor $\mathrm{pH}$ and metastasis: A malignant process beyond hypoxia. Cancer Metastasis Rev. 2019, 38, 113-129. [CrossRef]

12. Boedtkjer, E.; Pedersen, S.F. The acidic tumor microenvironment as a driver of cancer. Annu. Rev. Physiol. 2020, 82, 103-126. [CrossRef]

13. Gschwind, A.; Fischer, O.M.; Ullrich, A. The discovery of receptor tyrosine kinases: Targets for cancer therapy. Nat. Rev. Cancer 2004, 4, 361-370. [CrossRef]

14. Krause, D.S.; van Etten, R.A. Tyrosine kinases as targets for cancer therapy. N. Engl. J. Med. 2005, 353, 172-187. [CrossRef]

15. Muhammad, N.; Bhattacharya, S.; Steele, R.; Ray, R.B. Anti-miR-203 suppresses ER-positive breast cancer growth and stemness by targeting SOCS3. Oncotarget 2016, 7, 58595-58605. [CrossRef] [PubMed]

16. Rupaimoole, R.; Slack, F.J. MicroRNA therapeutics: Towards a new era for the management of cancer and other diseases. Nat. Rev. Drug Discov. 2017, 16, 203-221. [CrossRef]

17. Singh, S.V.; Ajay, A.K.; Mohammad, N.; Malvi, P.; Chaube, B.; Meena, A.S.; Bhat, M.K. Proteasomal inhibition sensitizes cervical cancer cells to mitomycin C-induced bystander effect: The role of tumor microenvironment. Cell Death Dis. 2015, 6, e1934. [CrossRef]

18. Soave, C.L.; Guerin, T.; Liu, J.; Dou, Q.P. Targeting the ubiquitin-proteasome system for cancer treatment: Discovering novel inhibitors from nature and drug repurposing. Cancer Metastasis Rev. 2017, 36, 717-736. [CrossRef]

19. Gillies, R.J.; Raghunand, N.; Garcia-Martin, M.L.; Gatenby, R.A. pH imaging. A review of pH measurement methods and applications in cancers. IEEE Eng. Med. Biol. Mag. 2004, 23, 57-64. [CrossRef]

20. Anemone, A.; Consolino, L.; Arena, F.; Capozza, M.; Longo, D.L. Imaging tumor acidosis: A survey of the available techniques for mapping in vivo tumor $\mathrm{pH}$. Cancer Metastasis Rev. 2019, 38, 25-49. [CrossRef]

21. Gatenby, R.A.; Gawlinski, E.T.; Gmitro, A.F.; Kaylor, B.; Gillies, R.J. Acid-mediated tumor invasion: A multidisciplinary study. Cancer Res. 2006, 66, 5216-5223. [CrossRef]

22. Estrella, V.; Chen, T.; Lloyd, M.; Wojtkowiak, J.; Cornnell, H.H.; Ibrahim-Hashim, A.; Bailey, K.; Balagurunathan, Y.; Rothberg, J.M.; Sloane, B.F.; et al. Acidity generated by the tumor microenvironment drives local invasion. Cancer Res. 2013, 73, 1524-1535. [CrossRef]

23. Bhujwalla, Z.M.; McCoy, C.L.; Glickson, J.D.; Gillies, R.J.; Stubbs, M. Estimations of intra- and extracellular volume and $\mathrm{pH}$ by 31P magnetic resonance spectroscopy: Effect of therapy on RIF-1 tumours. Br. J. Cancer 1998, 78, 606-611. [CrossRef]

24. McCoy, C.L.; Parkins, C.S.; Chaplin, D.J.; Griffiths, J.R.; Rodrigues, L.M.; Stubbs, M. The effect of blood flow modification on intra- and extracellular $\mathrm{pH}$ measured by 31P magnetic resonance spectroscopy in murine tumours. Br. J. Cancer 1995, 72, 905-911. [CrossRef]

25. Ojugo, A.; McSheehy, P.; McIntyre, D.; McCoy, C.; Stubbs, M.; Leach, M.; Judson, I.; Griffiths, J. Measurement of the extracellular $\mathrm{pH}$ of solid tumours in mice by magnetic resonance spectroscopy: A comparison of exogenous 19F and 31P probes. NMR Biomed. 1999, 12, 495-504. [CrossRef] 
26. Ardenkjær-Larsen, J.H.; Fridlund, B.; Gram, A.; Hansson, G.; Hansson, L.; Lerche, M.H.; Servin, R.; Thaning, M.; Golman, K. Increase in signal-to-noise ratio of $>10,000$ times in liquid-state NMR. Proc. Natl. Acad. Sci. 2003, 100, 10158-10163. [CrossRef]

27. Gallagher, F.A.; Kettunen, M.I.; Day, S.E.; Hu, D.-E.; Ardenkjaer-Larsen, J.H.; Jensen, P.R.; Karlsson, M.; Golman, K.; Lerche, M.H.; Brindle, K.M. Magnetic resonance imaging of $\mathrm{pH}$ in vivo using hyperpolarized 13C-labelled bicarbonate. Nature 2008, 453, 940-943. [CrossRef]

28. Gallagher, F.A.; Sladen, H.; Kettunen, M.I.; Serrao, E.M.; Rodrigues, T.B.; Wright, A.; Gill, A.B.; McGuire, S.; Booth, T.C.; Boren, J.; et al. Carbonic anhydrase activity monitored in vivo by hyperpolarized ${ }^{13} \mathrm{c}$-magnetic resonance spectroscopy demonstrates its importance for $\mathrm{pH}$ regulation in tumors. Cancer Res. 2015, 75, 4109-4118. [CrossRef]

29. Schroeder, M.A.; Swietach, P.; Atherton, H.J.; Gallagher, F.A.; Lee, P.; Radda, G.K.; Clarke, K.; Tyler, D.J. Measuring intracellular $\mathrm{pH}$ in the heart using hyperpolarized carbon dioxide and bicarbonate: A $13 \mathrm{C}$ and 31P magnetic resonance spectroscopy study. Cardiovasc. Res. 2010, 86, 82-91. [CrossRef]

30. Flavell, R.R.; von Morze, C.; Blecha, J.E.; Korenchan, D.E.; van Criekinge, M.; Sriram, R.; Gordon, J.W.; Chen, H.Y.; Subramaniam, S.; Bok, R.A.; et al. Application of Good's buffers to pH imaging using hyperpolarized 13C MRI. Chem. Commun. 2015, 51, 14119-14122. [CrossRef]

31. Korenchan, D.E.; Taglang, C.; von Morze, C.; Blecha, J.E.; Gordon, J.W.; Sriram, R.; Larson, P.E.Z.; Vigneron, D.B.; Vanbrocklin, H.F.; Kurhanewicz, J.; et al. Dicarboxylic acids as pH sensors for hyperpolarized 13C magnetic resonance spectroscopic imaging. Analyst 2017, 142, 1429-1433. [CrossRef]

32. Düwel, S.; Hundshammer, C.; Gersch, M.; Feuerecker, B.; Steiger, K.; Buck, A.; Walch, A.; Haase, A.; Glaser, S.J.; Schwaiger, A.; et al. Imaging of $\mathrm{pH}$ in vivo using hyperpolarized 13C-labelled zymonic acid. Nat. Commun. 2017, 8, 1-9. [CrossRef] [PubMed]

33. Hundshammer, C.; Düwel, S.; Ruseckas, D.; Topping, G.; Dzien, P.; Müller, C.; Feuerecker, B.; Hövener, J.B.; Haase, A.; Schwaiger, M.; et al. Hyperpolarized amino acid derivatives as multivalent magnetic resonance pH sensor molecules. Sensors 2018, 18, 600. [CrossRef] [PubMed]

34. Chen, L.Q.; Howison, C.M.; Jeffery, J.J.; Robey, I.F.; Kuo, P.H.; Pagel, M.D. Evaluations of extracellular pH within in vivo tumors using acidocest MRI. Magn. Reson. Med. 2014, 72, 1408-1417. [CrossRef]

35. Jones, K.M.; Randtke, E.A.; Yoshimaru, E.S.; Howison, C.M.; Chalasani, P.; Klein, R.R.; Chambers, S.K.; Kuo, P.H.; Pagel, M.D. Clinical translation of tumor acidosis measurements with AcidoCEST MRI. Mol. Imaging Biol. 2017, 19, 617-625. [CrossRef] [PubMed]

36. Martinez, G.V.; Zhang, X.; García-Martín, M.L.; Morse, D.L.; Woods, M.; Sherry, A.D.; Gillies, R.J. Imaging the extracellular $\mathrm{pH}$ of tumors by MRI after injection of a single cocktail of $\mathrm{T} 1$ and $\mathrm{T} 2$ contrast agents. NMR Biomed. 2011, 24, 1380-1391. [CrossRef]

37. Rottenberg, D.A.; Ginos, J.Z.; Kearfott, K.G.; Junck, L.; Dhawan, V.; Jarden, J.O. In vivo measurement of brain tumor pH using [11C] DMO and positron emission tomography. Ann. Neurol. 1985, 17, 70-79. [CrossRef]

38. Buxton, R.B.; Alpert, N.M.; Babikian, V.; Weise, S.; Correia, J.A.; Ackerman, R.H. Evaluation of the ${ }^{11} \mathrm{CO}_{2}$ positron emission tomographic method for measuring brain $\mathrm{pH}$. I. $\mathrm{pH}$ changes measured in states of altered $\mathrm{pCO}_{2}$. J. Cereb. Blood Flow Metab. 1987, 7, 709-719. [CrossRef]

39. Bauwens, M.; de Saint-Hubert, M.; Cleynhens, J.; Brams, L.; Devos, E.; Mottaghy, F.M.; Verbruggen, A. Radioiodinated Phenylalkyl Malonic acid derivatives as pH-sensitive SPECT tracers. PLoS ONE $2012,7$. [CrossRef]

40. Vavere, A.L.; Biddlecombe, G.B.; Spees, W.M.; Garbow, J.R.; Wijesinghe, D.; Andreev, O.A.; Engelman, D.M.; Reshetnyak, Y.K.; Lewis, J.S. A novel technology for the imaging of acidic prostate tumors by positron emission tomography. Cancer Res. 2009, 69, 4510-4516. [CrossRef]

41. Flavell, R.R.; Truillet, C.; Regan, M.K.; Ganguly, T.; Blecha, J.E.; Kurhanewicz, J.; Vanbrocklin, H.F.; Keshari, K.R.; Chang, C.J.; Evans, M.J.; et al. Caged [18F]FDG Glycosylamines for Imaging Acidic Tumor Microenvironments Using Positron Emission Tomography. Bioconjug. Chem. 2016, 27, 170-178. [CrossRef]

42. Swietach, P.; Vaughan-Jones, R.D.; Harris, A.L. Regulation of tumor $\mathrm{pH}$ and the role of carbonic anhydrase 9. Cancer Met. Rev. 2007, 26, 299-310. [CrossRef] [PubMed]

43. Leek, R.; Grimes, D.R.; Harris, A.L.; McIntyre, A. Methods: Using three-dimensional culture (spheroids) as an in vitro model of tumour hypoxia. Adv. Exp. Med. Biol. 2016, 899, 167-196. [PubMed]

44. Hanahan, D.; Weinberg, R.A. Hallmarks of cancer: The next generation. Cell 2011, 144, 646-674. [CrossRef] [PubMed] 
45. Swietach, P.; Patiar, S.; Supuran, C.T.; Harris, A.L.; Vaughan-Jones, R.D. The role of carbonic anhydrase 9 in regulating extracellular and intracellular ph in three-dimensional tumor cell growths. J. Biol. Chem. 2009, 284, 20299-20310. [CrossRef]

46. Clevers, H.; Tuveson, D.A. Organoid models for cancer research. Annu. Rev. Cancer Biol. 2019, 3, $223-234$. [CrossRef]

47. Shah, A.T.; Heaster, T.M.; Skala, M.C. Metabolic imaging of head and neck cancer organoids. PLoS ONE 2017, 12. [CrossRef] [PubMed]

48. Sharick, J.T.; Jeffery, J.J.; Karim, M.R.; Walsh, C.M.; Esbona, K.; Cook, R.S.; Skala, M.C. Cellular metabolic heterogeneity in vivo is recapitulated in tumor organoids. Neoplasia (USA) 2019, 21, 615-626. [CrossRef]

49. Guerin, M.V.; Finisguerra, V.; van den Eynde, B.J.; Bercovici, N.; Trautmann, A. Preclinical murine tumor models: A structural and functional perspective. eLife 2020, 9. [CrossRef]

50. Alquier, T.; Poitout, V. Considerations and guidelines for mouse metabolic phenotyping in diabetes research. Diabetologia 2018, 61, 526-538. [CrossRef]

51. Muir, A.; Danai, L.V.; Vander Heiden, M.G. Microenvironmental regulation of cancer cell metabolism: Implications for experimental design and translational studies. DMM Dis. Model. Mech. 2018, 11. [CrossRef]

52. Newell, K.; Franchi, A.; Pouyssegur, J.; Tannock, I. Studies with glycolysis-deficient cells suggest that production of lactic acid is not the only cause of tumor acidity. Proc. Natl. Acad. Sci. 1993, 90, 1127-1131. [CrossRef] [PubMed]

53. Yamagata, M.; Hasuda, K.; Stamato, T.; Tannock, I.F. The contribution of lactic acid to acidification of tumours: Studies of variant cells lacking lactate dehydrogenase. Br. J. Cancer 1998, 77, 1726-1731. [CrossRef] [PubMed]

54. Gullino, P.M.; Grantham, F.H.; Smith, S.H.; Haggerty, A.C. Modifications of the acid-base status of the internal milieu of tumors. J. Natl. Cancer Inst. 1965, 34, 857-869.

55. Vander Heiden, M.G.; Cantley, L.C.; Thompson, C.B. Understanding the Warburg effect: The metabolic requirements of cell proliferation. Science 2009, 324, 1029-1033. [CrossRef] [PubMed]

56. De Berardinis, R.J.; Chandel, N.S. Fundamentals of cancer metabolism. Sci. Adv. 2016, 2. [CrossRef]

57. Pavlova, N.N.; Thompson, C.B. The Emerging Hallmarks of Cancer Metabolism. Cell Metab. 2016, 23, 27-47. [CrossRef] [PubMed]

58. Hensley, C.T.; Faubert, B.; Yuan, Q.; Lev-Cohain, N.; Jin, E.; Kim, J.; Jiang, L.; Ko, B.; Skelton, R.; Loudat, L.; et al. Metabolic Heterogeneity in Human Lung Tumors. Cell 2016, 164, 681-694. [CrossRef]

59. Maher, E.A.; Marin-Valencia, I.; Bachoo, R.M.; Mashimo, T.; Raisanen, J.; Hatanpaa, K.J.; Jindal, A.; Jeffrey, F.M.; Choi, C.; Madden, C.; et al. Metabolism of [U-13C] glucose in human brain tumors in vivo. NMR Biomed. 2012, 25, 1234-1244. [CrossRef]

60. Caro, P.; Kishan, A.U.; Norberg, E.; Stanley, I.A.; Chapuy, B.; Ficarro, S.B.; Polak, K.; Tondera, D.; Gounarides, J.; Yin, H.; et al. Metabolic signatures uncover distinct targets in molecular subsets of diffuse large B cell lymphoma. Cancer Cell 2012, 22, 547-560. [CrossRef]

61. Davidson, S.M.; Papagiannakopoulos, T.; Olenchock, B.A.; Heyman, J.E.; Keibler, M.A.; Luengo, A.; Bauer, M.R.; Jha, A.K.; O’Brien, J.P.; Pierce, K.A.; et al. Environment impacts the metabolic dependencies of ras-driven non-small cell lung cancer. Cell Metab. 2016, 23, 517-528. [CrossRef] [PubMed]

62. Kallinowski, F.; Vaupel, P. pH distributions in spontaneous and isotransplanted rat tumours. Br. J. Cancer 1988, 58, 314-321. [CrossRef] [PubMed]

63. Kallinowski, F.; Schlenger, K.H.; Runkel, S.; Kloes, M.; Stohrer, M.; Okunieff, P.; Vaupel, P. Blood flow, metabolism, cellular microenvironment, and growth rate of human tumor xenografts. Cancer Res. 1989, 49, 3759-3764. [PubMed]

64. Holm, E.; Hagmüller, E.; Staedt, U.; Schlickeiser, G.; Günther, H.J.; Leweling, H.; Tokus, M.; Kollmar, H.B. Substrate balances across colonic carcinomas in humans. Cancer Res. 1995, 55, 1373-1378.

65. Stubbs, M.; Griffiths, J.R. The altered metabolism of tumors: HIF-1 and its role in the Warburg effect. Adv. Enzyme Regul. 2010, 50, 44-55. [CrossRef] [PubMed]

66. Mookerjee, S.A.; Gerencser, A.A.; Nicholls, D.G.; Brand, M.D. Quantifying intracellular rates of glycolytic and oxidative ATP production and consumption using extracellular flux measurements. J. Biol. Chem. 2017, 292, 7189-7207. [CrossRef] [PubMed]

67. Sly, W.S.; Hu, P.Y. Human carbonic anhydrases and carbonic anhydrase deficiencies. Annu. Rev. Biochem. 1995, 64, 375-401. [CrossRef] 
68. Wykoff, C.C.; Beasley, N.J.; Watson, P.H.; Turner, K.J.; Pastorek, J.; Sibtain, A.; Wilson, G.D.; Turley, H.; Talks, K.L.; Maxwell, P.H.; et al. Hypoxia-inducible expression of tumor-associated carbonic anhydrases. Cancer Res. 2000, 60, 7075-7083.

69. Mboge, M.Y.; Mahon, B.P.; McKenna, R.; Frost, S.C. Carbonic anhydrases: Role in pH control and cancer. Metabolites 2018, 8, 19. [CrossRef]

70. Pastorek, J.; Pastorekova, S.; Callebaut, I.; Mornon, J.P.; Zelnik, V.; Opavsky, R.; Zat'ovicova, M.; Liao, S.; Portetelle, D.; Stanbridge, E.J.; et al. Cloning and characterization of MN, a human tumor-associated protein with a domain homologous to carbonic anhydrase and a putative helix-loop-helix DNA binding segment. Oncogene 1994, 9, 2877-2888.

71. Zheng, Y.; Xu, B.; Zhao, Y.; Gu, H.; Li, C.; Wang, Y.; Chang, X. CA1 contributes to microcalcification and tumourigenesis in breast cancer. BMC Cancer 2015, 15. [CrossRef]

72. Wang, D.B.; Lu, X.K.; Zhang, X.; Li, Z.G.; Li, C.X. Carbonic anhydrase 1 is a promising biomarker for early detection of non-small cell lung cancer. Tumor Biol. 2016, 37, 553-559. [CrossRef] [PubMed]

73. Parkkila, A.K.; Herva, R.; Parkkila, S.; Rajaniemi, H. Immunohistochemical demonstration of human carbonic anhydrase isoenzyme II in brain tumours. Histochem. J. 1995, 27, 974-982. [CrossRef] [PubMed]

74. Parkkila, S.; Lasota, J.; Fletcher, J.A.; Ou, W.B.; Kivelä, A.J.; Nuorva, K.; Parkkila, A.K.; Ollikainen, J.; Sly, W.S.; Waheed, A.; et al. Carbonic anhydrase II. A novel biomarker for gastrointestinal stromal tumors. Mod. Pathol. 2010, 23, 743-750. [CrossRef]

75. Zhou, Y.; Mokhtari, R.B.; Pan, J.; Cutz, E.; Yeger, H. Carbonic anhydrase II mediates malignant behavior of pulmonary neuroendocrine tumors. Am. J. Respir. Cell Mol. Biol. 2015, 52, 183-192. [CrossRef] [PubMed]

76. Saarnio, J.; Parkkila, S.; Parkkila, A.K.; Waheed, A.; Casey, M.C.; Zhou, X.Y.; Pastoreková, S.; Pastorek, J.; Karttunen, T.; Haukipuro, K.; et al. Immunohistochemistry of carbonic anhydrase isozyme IX (MN/CA IX) in human gut reveals polarized expression in the epithelial cells with the highest proliferative capacity. J. Histochem. Cytochem. 1998, 46, 497-504. [CrossRef]

77. Ivanov, S.; Liao, S.Y.; Ivanova, A.; Danilkovitch-Miagkova, A.; Tarasova, N.; Weirich, G.; Merrill, M.J.; Proescholdt, M.A.; Oldfield, E.H.; Lee, J.; et al. Expression of hypoxia-inducible cell-surface transmembrane carbonic anhydrases in human cancer. Am. J. Pathol. 2001, 158, 905-919. [CrossRef]

78. Chiche, J.; Ilc, K.; Laferrière, J.; Trottier, E.; Dayan, F.; Mazure, N.M.; Brahimi-Horn, M.C.; Pouysségur, J. Hypoxia-inducible carbonic anhydrase IX and XII promote tumor cell growth by counteracting acidosis through the regulation of the intracellular $\mathrm{pH}$. Cancer Res. 2009, 69, 358-368. [CrossRef]

79. Lou, Y.; McDonald, P.C.; Oloumi, A.; Chia, S.; Ostlund, C.; Ahmadi, A.; Kyle, A.; Auf Dem Keller, U.; Leung, S.; Huntsman, D.; et al. Targeting tumor hypoxia: Suppression of breast tumor growth and metastasis by novel carbonic anhydrase IX inhibitors. Cancer Res. 2011, 71, 3364-3376. [CrossRef]

80. McIntyre, A.; Patiar, S.; Wigfield, S.; Li, J.L.; Ledaki, I.; Turley, H.; Leek, R.; Snell, C.; Gatter, K.; Sly, W.S.; et al. Carbonic anhydrase IX promotes tumor growth and necrosis in vivo and inhibition enhances anti-VEGF therapy. Clin. Cancer Res. 2012, 18, 3100-3111. [CrossRef]

81. Opavský, R.; Pastoreková, S.; Zelník, V.; Gibadulinová, A.; Stanbridge, E.J.; Závada, J.; Kettmann, R.; Pastorek, J. Human MN/CA9 gene, a novel member of the carbonic anhydrase family: Structure and exon to protein domain relationships. Genomics 1996, 33, 480-487. [CrossRef]

82. Závada, J.; Závadová, Z.; Pastorek, J.; Biesovä, Z.; Ježek, J.; Velek, J. Human tumour-associated cell adhesion protein MN/CA IX: Identification of M75 epitope and of the region mediating cell adhesion. Br. J. Cancer 2000, 82, 1808-1813. [CrossRef] [PubMed]

83. Csaderova, L.; Debreova, M.; Radvak, P.; Stano, M.; Vrestiakova, M.; Kopacek, J.; Pastorekova, S.; Svastova, E. The effect of carbonic anhydrase IX on focal contacts during cell spreading and migration. Front. Physiol. 2013, 4, 271. [CrossRef] [PubMed]

84. Innocenti, A.; Pastorekova, S.; Pastorek, J.; Scozzafava, A.; de Simone, G.; Supuran, C.T. The proteoglycan region of the tumor-associated carbonic anhydrase isoform IX acts as anintrinsic buffer optimizing $\mathrm{CO}_{2}$ hydration at acidic pH values characteristic of solid tumors. Bioorg. Med. Chem. Lett. 2009, 19, 5825-5828. [CrossRef] [PubMed]

85. Ames, S.; Pastorekova, S.; Becker, H.M. The proteoglycan-like domain of carbonic anhydrase IX mediates non-catalytic facilitation of lactate transport in cancer cells. Oncotarget 2018, 9, 27940-27957. [CrossRef]

86. Semenza, G.L. Hypoxia-inducible factors in physiology and medicine. Cell 2012, 148, 399-408. [CrossRef] 
87. Ratcliffe, P.J. Oxygen sensing and hypoxia signalling pathways in animals: The implications of physiology for cancer. J. Physiol. 2013, 591, 2027-2042. [CrossRef]

88. Wang, G.L.; Jiang, B.H.; Rue, E.A.; Semenza, G.L. Hypoxia-inducible factor 1 is a basic-helix-loop-helix-PAS heterodimer regulated by cellular $\mathrm{O}_{2}$ tension. Proc. Natl. Acad. Sci. 1995, 92, 5510-5514. [CrossRef]

89. Maxwell, P.H.; Wlesener, M.S.; Chang, G.W.; Clifford, S.C.; Vaux, E.C.; Cockman, M.E.; Wykoff, C.C.; Pugh, C.W.; Maher, E.R.; Ratcliffe, P.J. The tumour suppressor protein VHL targets hypoxia-inducible factors for oxygen-dependent proteolysis. Nature 1999, 399, 271-275. [CrossRef]

90. Forsythe, J.A.; Jiang, B.H.; Iyer, N.V.; Agani, F.; Leung, S.W.; Koos, R.D.; Semenza, G.L. Activation of vascular endothelial growth factor gene transcription by hypoxia-inducible factor 1. Mol. Cell. Biol. 1996, 16, 4604-4613. [CrossRef]

91. Firth, J.D.; Ebert, B.L.; Ratcliffe, P.J. Hypoxic regulation of lactate dehydrogenase A: Interaction between hypoxia-inducible factor 1 and cAMP response elements. J. Biol. Chem. 1995, 270, 21021-21027. [CrossRef]

92. Ebert, B.L.; Firth, J.D.; Ratcliffe, P.J. Hypoxia and mitochondrial inhibitors regulate expression of glucose transporter-1 via distinct cis-acting sequences. J. Biol. Chem. 1995, 270, 29083-29089. [CrossRef] [PubMed]

93. Chen, C.; Pore, N.; Behrooz, A.; Ismail-Beigi, F.; Maity, A. Regulation of glut1 mRNA by hypoxia-inducible factor-1: Interaction between H-ras and hypoxia. J. Biol. Chem. 2001, 276, 9519-9525. [CrossRef] [PubMed]

94. Kaluz, S.; Kaluzová, M.; Liao, S.Y.; Lerman, M.; Stanbridge, E.J. Transcriptional control of the tumor- and hypoxia-marker carbonic anhydrase 9: A one transcription factor (HIF-1) show? Biochim. Biophys. 2009, 1795, 162-172. [CrossRef]

95. Krieg, M.; Haas, R.; Brauch, H.; Acker, T.; Flamme, I.; Plate, K.H. Up-regulation of hypoxia-inducible factors HIF- $1 \alpha$ and HIF- $2 \alpha$ under normoxic conditions in renal carcinoma cells by von Hippel-Lindau tumor suppressor gene loss of function. Oncogene 2000, 19, 5435-5443. [CrossRef] [PubMed]

96. Shen, C.; Kaelin, W.G. The VHL/HIF axis in clear cell renal carcinoma. Semin. Cancer Biol. 2013, $23,18-25$. [CrossRef]

97. Laughner, E.; Taghavi, P.; Chiles, K.; Mahon, P.C.; Semenza, G.L. HER2 (neu) Signaling Increases the Rate of Hypoxia-Inducible Factor $1 \alpha$ (HIF-1 $\alpha$ ) Synthesis: Novel Mechanism for HIF-1-Mediated Vascular Endothelial Growth Factor Expression. Mol. Cell. Biol. 2001, 21, 3995-4004. [CrossRef]

98. Kaluz, S.; Kaluzová, M.; Chrastina, A.; Olive, P.L.; Pastoreková, S.; Pastorek, J.; Lerman, M.I.; Stanbridge, E.J. Lowered oxygen tension induces expression of the hypoxia marker MN/carbonic anhydrase IX in the absence of hypoxia-inducible factor $1 \alpha$ stabilization: A role for phosphatidylinositol 3'-kinase. Cancer Res. 2002, 62, $4469-4477$.

99. Kopacek, J.; Barathova, M.; Dequiedt, F.; Sepelakova, J.; Kettmann, R.; Pastorek, J.; Pastorekova, S. MAPK pathway contributes to density- and hypoxia-induced expression of the tumor-associated carbonic anhydrase IX. Biochim. Biophys. Acta 2005, 1729, 41-49. [CrossRef]

100. Pastorek, J.; Takacova, M.; Holotnakova, T.; Barathova, M.; Pastorekova, S.; Kopacek, J. Src induces expression of carbonic anhydrase IX via hypoxia-inducible factor 1. Oncol. Rep. 2010, 23, 869-874.

101. Takacova, M.; Bullova, P.; Simko, V.; Skvarkova, L.; Poturnajova, M.; Feketeova, L.; Babal, P.; Kivela, A.J.; Kuopio, T.; Kopacek, J.; et al. Expression pattern of carbonic anhydrase IX in medullary thyroid carcinoma supports a role for RET-mediated activation of the HIF pathway. Am. J. Pathol. 2014, 184, 953-965. [CrossRef]

102. Zundel, W.; Schindler, C.; Haas-Kogan, D.; Koong, A.; Kaper, F.; Chen, E.; Gottschalk, A.R.; Ryan, H.E.; Johnson, R.S.; Jefferson, A.B.; et al. Loss of PTEN facilitates HIF-1-mediated gene expression. Genes Dev. 2000, 14, 391-396. [PubMed]

103. Brugarolas, J.; Kaelin, W.G. Dysregulation of HIF and VEGF is a unifying feature of the familial hamartoma syndromes. Cancer Cell 2004, 6, 7-10. [CrossRef] [PubMed]

104. Bernardi, R.; Guernah, I.; Jin, D.; Grisendi, S.; Alimonti, A.; Teruya-Feldstein, J.; Cordon-Cardo, C.; Celeste Simon, M.; Rafii, S.; Pandolfi, P.P. PML inhibits HIF-1 $\alpha$ translation and neoangiogenesis through repression of mTOR. Nature 2006, 442, 779-785. [CrossRef]

105. Isaacs, J.S.; Yun, J.J.; Mole, D.R.; Lee, S.; Torres-Cabala, C.; Chung, Y.L.; Merino, M.; Trepel, J.; Zbar, B.; Toro, J.; et al. HIF overexpression correlates with biallelic loss of fumarate hydratase in renal cancer: Novel role of fumarate in regulation of HIF stability. Cancer Cell 2005, 8, 143-153. [CrossRef]

106. Pollard, P.J.; Brière, J.J.; Alam, N.A.; Barwell, J.; Barclay, E.; Wortham, N.C.; Hunt, T.; Mitchell, M.; Olpin, S.; Moat, S.J.; et al. Accumulation of Krebs cycle intermediates and over-expression of HIF1 $\alpha$ in tumours which result from germline FH and SDH mutations. Hum. Mol. Genet. 2005, 14, 2231-2239. [CrossRef] [PubMed] 
107. Selak, M.A.; Armour, S.M.; MacKenzie, E.D.; Boulahbel, H.; Watson, D.G.; Mansfield, K.D.; Pan, Y.; Simon, M.C.; Thompson, C.B.; Gottlieb, E. Succinate links TCA cycle dysfunction to oncogenesis by inhibiting HIF- $\alpha$ prolyl hydroxylase. Cancer Cell 2005, 7, 77-85. [CrossRef]

108. Hewitson, K.S.; Liénard, B.M.R.; McDonough, M.A.; Clifton, I.J.; Butler, D.; Soares, A.S.; Oldham, N.J.; McNeill, L.A.; Schofield, C.J. Structural and mechanistic studies on the inhibition of the hypoxia-inducible transcription factor hydroxylases by tricarboxylic acid cycle intermediates. J. Biol. Chem. 2007, 282, 3293-3301. [CrossRef]

109. O’Flaherty, L.; Adam, J.; Heather, L.C.; Zhdanov, A.V.; Chung, Y.-L.; Miranda, M.X.; Croft, J.; Olpin, S.; Clarke, K.; Pugh, C.W.; et al. Dysregulation of hypoxia pathways in fumarate hydratase-deficient cells is independent of defective mitochondrial metabolism. Hum. Mol. Genet. 2010, 19, 3844-3851. [CrossRef]

110. Chia, S.K.; Wykoff, C.C.; Watson, P.H.; Han, C.; Leek, R.D.; Pastorek, J.; Gatter, K.C.; Ratcliffe, P.; Harris, A.L. Prognostic significance of a novel hypoxia-regulated marker, carbonic anhydrase IX, in invasive breast carcinoma. J. Clin. Oncol. 2001, 19, 3660-3668. [CrossRef]

111. Generali, D.; Fox, S.B.; Berruti, A.; Brizzi, M.P.; Campo, L.; Bonardi, S.; Wigfield, S.M.; Bruzzi, P.; Bersiga, A.; Allevi, G.; et al. Role of carbonic anhydrase IX expression in prediction of the efficacy and outcome of primary epirubicin/tamoxifen therapy for breast cancer. Endocr. Relat. Cancer 2006, 13, 921-930. [CrossRef]

112. Saarnio, J.; Parkkila, S.; Parkkila, A.K.; Haukipuro, K.; Pastorekova, S.; Pastorek, J.; Kairaluoma, M.I.; Karttunen, T.J. Immunohistochemical study of colorectal tumors for expression of a novel transmembrane carbonic anhydrase, MN/CA IX, with potential value as a marker of cell proliferation. Am. J. Pathol. 1998, 153, 279-285. [CrossRef]

113. Haapasalo, J.A.; Nordfors, K.M.; Hilvo, M.; Rantala, I.J.; Soini, Y.; Parkkila, A.K.; Pastoreková, S.; Pastorek, J.; Parkkila, S.M.; Haapasalo, H.K. Expression of carbonic anhydrase IX in astrocytic tumors predicts poor prognosis. Clin. Cancer Res. 2006, 12, 473-477. [CrossRef] [PubMed]

114. Giatromanolaki, A.; Koukourakis, M.I.; Sivridis, E.; Pastorek, J.; Wykoff, C.C.; Gatter, K.C.; Harris, A.L. Expression of hypoxia-inducible carbonic anhydrase-9 relates to angiogenic pathways and independently to poor outcome in non-small cell lung cancer. Cancer Res. 2001, 61, 7992-7998. [PubMed]

115. Beasley, N.J.; Wykoff, C.C.; Watson, P.H.; Leek, R.; Turley, H.; Gatter, K.; Pastorek, J.; Cox, G.J.; Ratcliffe, P.; Harris, A.L. Carbonic anhydrase IX, an endogenous hypoxia marker, expression in head and neck squamous cell carcinoma and its relationship to hypoxia, necrosis, and microvessel density. Cancer Res. 2001, 61, 5262-5267. [PubMed]

116. Koukourakis, M.I.; Giatromanolaki, A.; Sivridis, E.; Simopoulos, K.; Pastorek, J.; Wykoff, C.C.; Gatter, K.C.; Harris, A.L. Hypoxia-regulated carbonic anhydrase-9 (CA9) relates to poor vascularization and resistance of squamous cell head and neck cancer to chemoradiotherapy. Clin. Cancer Res. 2001, 7, 3399-3403.

117. Liao, S.Y.; Brewer, C.; Závada, J.; Pastorek, J.; Pastorekova, S.; Manetta, A.; Berman, M.L.; DiSaia, P.J.; Stanbridge, E.J. Identification of the MN antigen as a diagnostic biomarker of cervical intraepithelial squamous and glandular neoplasia and cervical carcinomas. Am. J. Pathol. 1994, 145, 598-609.

118. Svastova, E.; Witarski, W.; Csaderova, L.; Kosik, I.; Skvarkova, L.; Hulikova, A.; Zatovicova, M.; Barathova, M.; Kopacek, J.; Pastorek, J.; et al. Carbonic anhydrase IX interacts with bicarbonate transporters in lamellipodia and increases cell migration via its catalytic domain. J. Biol. Chem. 2012, 287, 3392-3402. [CrossRef]

119. Debreova, M.; Csaderova, L.; Burikova, M.; Lukacikova, L.; Kajanova, I.; Sedlakova, O.; Kery, M.; Kopacek, J.; Zatovicova, M.; Bizik, J.; et al. CAIX regulates invadopodia formation through both a pH-dependent mechanism and interplay with actin regulatory proteins. Int. J. Mol. Sci. 2019, 20, 2745. [CrossRef]

120. Shin, H.J.; Rho, S.B.; Jung, D.C.; Han, I.O.; Oh, E.S.; Kim, J.Y. Carbonic anhydrase IX (CA9) modulates tumor associated cell migration and invasion. J. Cell Sci. 2011, 124, 1077-1087. [CrossRef]

121. Mani, S.A.; Guo, W.; Liao, M.J.; Eaton, E.N.; Ayyanan, A.; Zhou, A.Y.; Brooks, M.; Reinhard, F.; Zhang, C.C.; Shipitsin, M.; et al. The Epithelial-Mesenchymal Transition Generates Cells with Properties of Stem Cells. Cell 2008, 133, 704-715. [CrossRef]

122. Nassar, D.; Blanpain, C. Cancer Stem Cells: Basic Concepts and Therapeutic Implications. Annu. Rev. Pathol. Mech. Dis. 2016, 11, 47-76. [CrossRef]

123. Das, B.; Tsuchida, R.; Malkin, D.; Koren, G.; Baruchel, S.; Yeger, H. Hypoxia Enhances Tumor Stemness by Increasing the Invasive and Tumorigenic Side Population Fraction. Stem Cells 2008, 26, 1818-1830. [CrossRef] [PubMed] 
124. Mohyeldin, A.; Garzón-Muvdi, T.; Quiñones-Hinojosa, A. Oxygen in stem cell biology: A critical component of the stem cell niche. Cell Stem Cell 2010, 7, 150-161. [CrossRef] [PubMed]

125. Lock, F.E.; McDonald, P.C.; Lou, Y.; Serrano, I.; Chafe, S.C.; Ostlund, C.; Aparicio, S.; Winum, J.Y.; Supuran, C.T.; Dedhar, S. Targeting carbonic anhydrase IX depletes breast cancer stem cells within the hypoxic niche. Oncogene 2013, 32, 5210-5219. [CrossRef]

126. Ledaki, I.; McIntyre, A.; Wigfield, S.; Buffa, F.; McGowan, S.; Baban, D.; Li, J.-L.; Harris, A.L. Carbonic anhydrase IX induction defines a heterogeneous cancer cell response to hypoxia and mediates stem cell-like properties and sensitivity to HDAC inhibition. Oncotarget 2015, 6, 19413-19427. [CrossRef] [PubMed]

127. Swietach, P.; Wigfield, S.; Cobden, P.; Supuran, C.T.; Harris, A.L.; Vaughan-Jones, R.D. Tumor-associated carbonic anhydrase 9 spatially coordinates intracellular $\mathrm{pH}$ in three-dimensional multicellular growths. J. Biol. Chem. 2008, 283, 20473-20483. [CrossRef]

128. Jacobs, M.H.; Stewart, D.R. The role of carbonic anhydrase in certain ionic exchanges involving the erythrocyte. J. Gen. Physiol. 1942, 25, 539-552. [CrossRef]

129. Stubbs, M.; McSheehy, P.M.J.; Griffiths, J.R. Causes and consequences of acidic pH in tumors: A magnetic resonance study. Adv. Enzyme Regul. 1999, 39, 13-30. [CrossRef]

130. Alterio, V.; Hilvo, M.; di Fiore, A.; Supuran, C.T.; Pan, P.; Parkkila, S.; Scaloni, A.; Pastorek, J.; Pastorekova, S.; Pedone, C.; et al. Crystal structure of the catalytic domain of the tumor-associated human carbonic anhydrase IX. Proc. Natl. Acad. Sci. 2009, 106, 16233-16238. [CrossRef]

131. Li, Y.; Tu, C.; Wang, H.; Silverman, D.N.; Frost, S.C. Catalysis and pH control by membrane-associated carbonic anhydrase IX in MDA-MB-231 breast cancer cells. J. Biol. Chem. 2011, 286, 15789-15796. [CrossRef]

132. Mahon, B.P.; Bhatt, A.; Socorro, L.; Driscoll, J.M.; Okoh, C.; Lomelino, C.L.; Mboge, M.Y.; Kurian, J.J.; Tu, C.; Agbandje-Mckenna, M.; et al. The structure of carbonic anhydrase IX is adapted for low-pH catalysis. Biochemistry 2016, 55, 4642-4653. [CrossRef] [PubMed]

133. Chen, L.Q.; Howison, C.M.; Spier, C.; Stopeck, A.T.; Malm, S.W.; Pagel, M.D.; Baker, A.F. Assessment of carbonic anhydrase IX expression and extracellular $\mathrm{pH}$ in B-cell lymphoma cell line models. Leuk. Lymphoma 2015, 56, 1432-1439. [CrossRef] [PubMed]

134. Lee, S.H.; McIntyre, D.; Honess, D.; Hulikova, A.; Pacheco-Torres, J.; Cerdán, S.; Swietach, P.; Harris, A.L.; Griffiths, J.R. Carbonic anhydrase IX is a $\mathrm{pH}$-stat that sets an acidic tumour extracellular $\mathrm{pH}$ in vivo. Br. J. Cancer 2018, 119, 622-630. [CrossRef]

135. Thomlinson, R.H.; Gray, L.H. The histological structure of some human lung cancers and the possible implications for radiotherapy. Br. J. Cancer 1955, 9, 539-549. [CrossRef] [PubMed]

136. Semenza, G.L.; Roth, P.H.; Fang, H.M.; Wang, G.L. Transcriptional regulation of genes encoding glycolytic enzymes by hypoxia-inducible factor 1. J. Biol. Chem. 1994, 269, 23757-23763. [PubMed]

137. Ullah, M.S.; Davies, A.J.; Halestrap, A.P. The plasma membrane lactate transporter MCT4, but not MCT1, is up-regulated by hypoxia through a HIF-1 $\alpha$-dependent mechanism. J. Biol. Chem. 2006, 281, 9030-9037. [CrossRef]

138. Gatenby, R.A. Models of tumor-host interaction as competing populations: Implications for tumor biology and treatment. J. Theor. Biol. 1995, 176, 447-455. [CrossRef]

139. Rozhin, J.; Sameni, M.; Ziegler, G.; Sloane, B.F. Pericellular $\mathrm{pH}$ affects distribution and secretion of cathepsin $\mathrm{b}$ in malignant cells. Cancer Res. 1994, 54, 6517-6525.

140. Rothberg, J.M.; Bailey, K.M.; Wojtkowiak, J.W.; Ben-Nun, Y.; Bogyo, M.; Weber, E.; Moin, K.; Blum, G.; Mattingly, R.R.; Gillies, R.J.; et al. Acid-mediated tumor proteolysis: Contribution of cysteine cathepsins. Neoplasia (USA) 2013, 15, 1125-1137. [CrossRef]

141. Gatenby, R.A.; Gawlinski, E.T. The glycolytic phenotype in carcinogenesis and tumor invasion: Insights through mathematical models. Cancer Res. 2003, 63, 3847-3854.

142. Gatenby, R.A.; Gillies, R.J. A microenvironmental model of carcinogenesis. Nat. Rev. Cancer 2008, 8, 56-61. [CrossRef] [PubMed]

143. Lloyd, M.C.; Cunningham, J.J.; Bui, M.M.; Gillies, R.J.; Brown, J.S.; Gatenby, R.A. Darwinian dynamics of intratumoral heterogeneity: Not solely random mutations but also variable environmental selection forces. Cancer Res. 2016, 76, 3136-3144. [CrossRef]

144. Wiesener, M.S.; Münchenhagen, P.M.; Schwiertz, A.; Jürgensen, J.S.; Gruber, G.; Frei, U.; Eckardt, K.U.; Roigas, J.; Löning, S.A.; Berger, I.; et al. Constitutive activation of hypoxia-inducible genes related to overexpression of hypoxia-inducible factor- $1 \alpha$ in clear cell renal carcinomas. Cancer Res. 2001, 61, 5215-5222. 
145. Stillebroer, A.B.; Mulders, P.F.A.; Boerman, O.C.; Oyen, W.J.G.; Oosterwijk, E. Carbonic anhydrase IX in renal cell carcinoma: Implications for prognosis, diagnosis, and therapy. Eur. Urol. 2010, 58, 75-83. [CrossRef]

146. Bui, M.H.T.; Seligson, D.; Han, K.R.; Pantuck, A.J.; Dorey, F.J.; Huang, Y.; Horvath, S.; Leibovich, B.C.; Chopra, S.; Liao, S.Y.; et al. Carbonic anhydrase IX is an independent predictor of survival in advanced renal clear cell carcinoma: Implications for prognosis and therapy. Clin. Cancer Res. 2003, 9, 802-811.

147. Bartoov, M.; Parkkila, S.; Pohlodek, K.; Karttunen, T.J.; Galbav, T.; Mucha, V.; Harris, A.L.; Pastorek, J.; Pastorekov, S. Expression of carbonic anhydrase IX in breast is associated with malignant tissues and is related to overexpression of c-erbB2. J. Pathol. 2002, 197, 314-321. [CrossRef]

148. Schoppmann, S.F.; Jesch, B.; Friedrich, J.; Jomrich, G.; Maroske, F.; Birner, P. Phosphorylation of signal transducer and activator of transcription 3 (STAT3) correlates with Her-2 status, carbonic anhydrase 9 expression and prognosis in esophageal cancer. Clin. Exp. Metastasis 2012, 29, 615-624. [CrossRef]

149. Swinson, D.E.B.; Jones, J.L.; Cox, G.; Richardson, D.; Harris, A.L.; O’Byrne, K.J. Hypoxia-inducible factor- $1 \alpha$ in non small cell lung cancer: Relation to growth factor, protease and apoptosis pathways. Int. J. Cancer 2004, 111, 43-50. [CrossRef]

150. Le, Q.T.; Chen, E.; Salim, A.; Cao, H.; Kong, C.S.; Whyte, R.; Donington, J.; Cannon, W.; Wakelee, H.; Tibshirani, R.; et al. An evaluation of tumor oxygenation and gene expression in patients with early stage non-small cell lung cancers. Clin. Cancer Res. 2006, 12, 1507-1514. [CrossRef]

151. Brennan, D.J.; Jirstrom, K.; Kronblad, Å.; Millikan, R.C.; Landberg, G.; Duffy, M.J.; Rydén, L.; Gallagher, W.M.; $\mathrm{O}^{\prime}$ Brien, S.L. CA IX is an independent prognostic marker in premenopausal breast cancer patients with one to three positive lymph nodes and a putative marker of radiation resistance. Clin. Cancer Res. 2006, 12, 6421-6431. [CrossRef]

152. Brockton, N.; Dort, J.; Lau, H.; Hao, D.; Brar, S.; Klimowicz, A.; Petrillo, S.; Diaz, R.; Doll, C.; Magliocco, A. High stromal carbonic anhydrase ix expression is associated with decreased survival in p16-negative head-and-neck tumors. Int. J. Radiat. Oncol. Biol. Phys. 2011, 80, 249-257. [CrossRef]

153. Závada, J.; Závadová, Z.; Zat'ovičová, M.; Hyršl, L.; Kawaciuk, I. Soluble form of carbonic anhydrase IX (CA IX) in the serum and urine of renal carcinoma patients. Br. J. Cancer 2003, 89, 1067-1071. [CrossRef]

154. Janning, M.; Müller, V.; Vettorazzi, E.; Cubas-Cordova, M.; Gensch, V.; Ben-Batalla, I.; zu Eulenburg, C.; Schem, C.; Fasching, P.A.; Schnappauf, B.; et al. Evaluation of soluble carbonic anhydrase IX as predictive marker for efficacy of bevacizumab: A biomarker analysis from the geparquinto phase III neoadjuvant breast cancer trial. Int. J. Cancer 2019, 145, 857-868. [CrossRef]

155. Van Kuijk, S.J.A.; Yaromina, A.; Houben, R.; Niemans, R.; Lambin, P.; Dubois, L.J. Prognostic significance of carbonic anhydrase IX expression in cancer patients: A meta-analysis. Front. Oncol. 2016, 6. [CrossRef]

156. Tan, E.Y.; Yan, M.; Campo, L.; Han, C.; Takano, E.; Turley, H.; Candiloro, I.; Pezzella, F.; Gatter, K.C.; Millar, E.K.A.; et al. The key hypoxia regulated gene CAIX is upregulated in basal-like breast tumours and is associated with resistance to chemotherapy. Br. J. Cancer 2009, 100, 405-411. [CrossRef]

157. Koukourakis, M.I.; Bentzen, S.M.; Giatromanolaki, A.; Wilson, G.D.; Daley, F.M.; Saunders, M.I.; Dische, S.; Sivridis, E.; Harris, A.L. Endogenous markers of two separate hypoxia response pathways (hypoxia inducible factor 2 alpha and carbonic anhydrase 9) are associated with radiotherapy failure in head and neck cancer patients recruited in the CHART randomized trial. J. Clin. Oncol. 2006, 24, 727-735. [CrossRef]

158. Chafe, S.C.; McDonald, P.C.; Saberi, S.; Nemirovsky, O.; Venkateswaran, G.; Burugu, S.; Gao, D.; Delaidelli, A.; Kyle, A.H.; Baker, J.H.E.; et al. Targeting hypoxia-induced carbonic anhydrase IX enhances immune-checkpoint blockade locally and systemically. Cancer Immunol. Res. 2019, 7, 1064-1078. [CrossRef]

159. Supuran, C.T. Carbonic anhydrase inhibitors as emerging agents for the treatment and imaging of hypoxic tumors. Expert Opin. Investig. Drugs 2018, 27, 963-970. [CrossRef]

160. Safety Study of SLC-0111 in Subjects with Advanced Solid Tumours-Full Text View-ClinicalTrials.gov. Available online: https://clinicaltrials.gov/ct2/show/NCT02215850 (accessed on 5 March 2020).

161. A Study of SLC-0111 and Gemcitabine for Metastatic Pancreatic Ductal Cancer in Subjects Positive for CAIX-Full Text View-ClinicalTrials.gov. Available online: https://clinicaltrials.gov/ct2/show/NCT03450018 (accessed on 11 March 2020).

162. Hedlund, E.M.; McDonald, P.C.; Nemirovsky, O.; Awrey, S.; Jensen, L.D.E.; Dedhar, S. Harnessing induced essentiality: Targeting carbonic anhydrase IX and angiogenesis reduces lung metastasis of triple negative breast cancer xenografts. Cancers (Basel) 2019, 11, 1002. [CrossRef] [PubMed] 
163. Dubois, L.; Peeters, S.G.J.A.; van Kuijk, S.J.A.; Yaromina, A.; Lieuwes, N.G.; Saraya, R.; Biemans, R.; Rami, M.; Parvathaneni, N.K.; Vullo, D.; et al. Targeting carbonic anhydrase IX by nitroimidazole based sulfamides enhances the therapeutic effect of tumor irradiation: A new concept of dual targeting drugs. Radiother. Oncol. 2013, 108, 523-528. [CrossRef]

164. Chamie, K.; Klöpfer, P.; Bevan, P.; Störkel, S.; Said, J.; Fall, B.; Belldegrun, A.S.; Pantuck, A.J. Carbonic anhydrase-IX score is a novel biomarker that predicts recurrence and survival for high-risk, nonmetastatic renal cell carcinoma: Data from the phase III ARISER clinical trial. Urol. Oncol. Semin. Orig. Investig. 2015, 33. [CrossRef]

165. Van Laarhoven, H.W.M.; Kaanders, J.H.A.M.; Lok, J.; Peeters, W.J.M.; Rijken, P.F.J.W.; Wiering, B.; Ruers, T.J.M.; Punt, C.J.A.; Heerschap, A.; van der Kogel, A.J. Hypoxia in relation to vasculature and proliferation in liver metastases in patients with colorectal cancer. Int. J. Radiat. Oncol. Biol. Phys. 2006, 64, 473-482. [CrossRef]

166. Tafreshi, N.K.; Bui, M.M.; Bishop, K.; Lloyd, M.C.; Enkemann, S.A.; Lopez, A.S.; Abrahams, D.; Carter, B.W.; Vagner, J.; Gobmyer, S.R.; et al. Noninvasive detection of breast cancer lymph node metastasis using carbonic anhydrases IX and XII targeted imaging probes. Clin. Cancer Res. 2012, 18, 207-219. [CrossRef]

167. Kim, H.M.; Jung, W.H.; Koo, J.S. Site-specific metabolic phenotypes in metastatic breast cancer. J. Transl. Med. 2014, 12. [CrossRef]

168. Guerra, F.; Arbini, A.A.; Moro, L. Mitochondria and cancer chemoresistance. Biochim. Biophys. Acta 2017, 1858, 686-699. [CrossRef]

169. Bosc, C.; Selak, M.A.; Sarry, J.E. Resistance is futile: Targeting mitochondrial energetics and metabolism to overcome drug resistance in cancer treatment. Cell Metab. 2017, 26, 705-707. [CrossRef]

170. Vazquez, F.; Lim, J.H.; Chim, H.; Bhalla, K.; Girnun, G.; Pierce, K.; Clish, C.B.; Granter, S.R.; Widlund, H.R.; Spiegelman, B.M.; et al. PGC1 $\alpha$ expression defines a subset of human melanoma tumors with increased mitochondrial capacity and resistance to oxidative stress. Cancer Cell 2013, 23, 287-301. [CrossRef]

171. Viale, A.; Pettazzoni, P.; Lyssiotis, C.A.; Ying, H.; Sánchez, N.; Marchesini, M.; Carugo, A.; Green, T.; Seth, S.; Giuliani, V.; et al. Oncogene ablation-resistant pancreatic cancer cells depend on mitochondrial function. Nature 2014, 514, 628-632. [CrossRef]

172. Lee, K.M.; Giltnane, J.M.; Balko, J.M.; Schwarz, L.J.; Guerrero-Zotano, A.L.; Hutchinson, K.E.; Nixon, M.J.; Estrada, M.V.; Sánchez, V.; Sanders, M.E.; et al. MYC and MCL1 cooperatively promote chemotherapy-resistant breast cancer stem cells via regulation of mitochondrial oxidative phosphorylation. Cell Metab. 2017, 26, 633-647.e7. [CrossRef]

173. Muus, P.; van den Bogert, C.; de Vries, H.; Pennings, A.; Holtrop, M.; Haanen, C. 1- $\beta-D-A r$ abinofuranosylcytosine (Ara-C) enhances mitochondrial activities in human leukaemic cells. Br. J. Cancer 1991, 64, 29-34. [CrossRef]

174. Henkenius, K.; Greene, B.H.; Barckhausen, C.; Hartmann, R.; Märken, M.; Kaiser, T.; Rehberger, M.; Metzelder, S.K.; Parak, W.J.; Neubauer, A.; et al. Maintenance of cellular respiration indicates drug resistance in acute myeloid leukemia. Leuk. Res. 2017, 62, 56-63. [CrossRef]

175. Farge, T.; Saland, E.; de Toni, F.; Aroua, N.; Hosseini, M.; Perry, R.; Bosc, C.; Sugita, M.; Stuani, L.; Fraisse, M.; et al. Chemotherapy-resistant human acute myeloid leukemia cells are not enriched for leukemic stem cells but require oxidative metabolism. Cancer Discov. 2017, 7, 716-735. [CrossRef]

176. Martin, M.J.; Eberlein, C.; Taylor, M.; Ashton, S.; Robinson, D.; Cross, D. Inhibition of oxidative phosphorylation suppresses the development of osimertinib resistance in a preclinical model of EGFR-driven lung adenocarcinoma. Oncotarget 2016, 7, 86313-86325. [CrossRef]

177. Ippolito, L.; Marini, A.; Cavallini, L.; Morandi, A.; Pietrovito, L.; Pintus, G.; Giannoni, E.; Schrader, T.; Puhr, M.; Chiarugi, P.; et al. Metabolic shift toward oxidative phosphorylation in docetaxel resistant prostate cancer cells. Oncotarget 2016, 7, 61890-61904. [CrossRef]

178. Gopal, Y.N.V.; Gammon, S.; Prasad, R.; Knighton, B.; Pisaneschi, F.; Roszik, J.; Feng, N.; Johnson, S.; Pramanik, S.; Sudderth, J.; et al. A novel mitochondrial inhibitor blocks MAPK pathway and overcomes MAPK inhibitor resistance in melanoma. Clin. Cancer Res. 2019, 25, 6429-6442. 
179. Denise, C.; Paoli, P.; Calvani, M.; Taddei, M.L.; Giannoni, E.; Kopetz, S.; Kazmi, S.M.A.; Pia, M.M.; Pettazzoni, P.; Sacco, E.; et al. 5-Fluorouracil resistant colon cancer cells are addicted to OXPHOS to survive and enhance stem-like traits. Oncotarget 2015, 6, 41706-41721. [CrossRef]

180. Ashton, T.M.; Gillies Mckenna, W.; Kunz-Schughart, L.A.; Higgins, G.S. Oxidative Phosphorylation as an Emerging Target in Cancer Therapy. Clin. Cancer Res. 2018, 24. [CrossRef]

(C) 2020 by the authors. Licensee MDPI, Basel, Switzerland. This article is an open access article distributed under the terms and conditions of the Creative Commons Attribution (CC BY) license (http://creativecommons.org/licenses/by/4.0/). 